\title{
Biocide Usage in Cooling Towers in the Electric Power and Petroleum Refining Industries
}

\author{
Prepared for: $\quad$ U.S. Department of Energy \\ Office of Fossil Energy \\ Under Contract W-31-109-ENG-38 \\ Prepared by: John A. Veil, James K. Rice, and Mary E.S. Raivel \\ Argonne National Laboratory \\ Washington, DC
}

September 1997 


\section{Table of Contents}

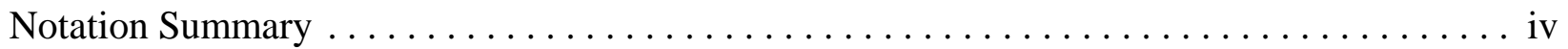

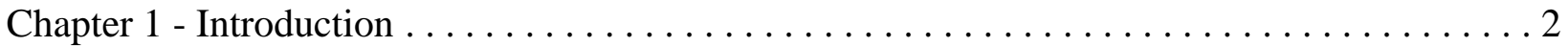

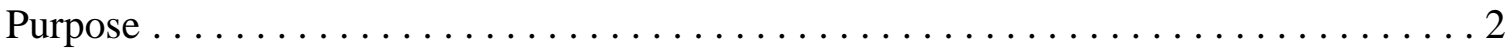

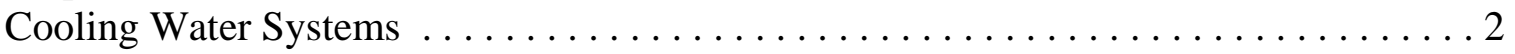

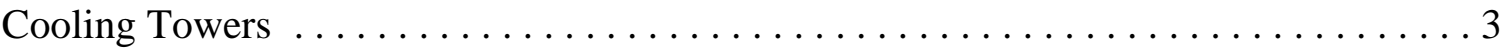

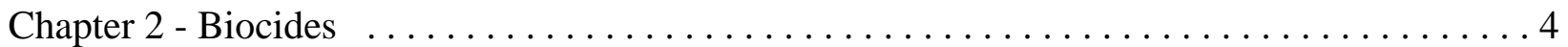

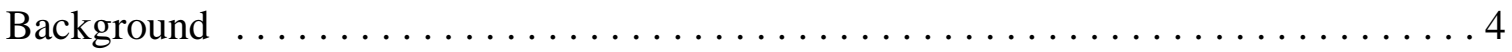

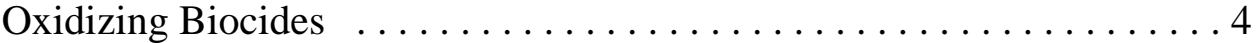

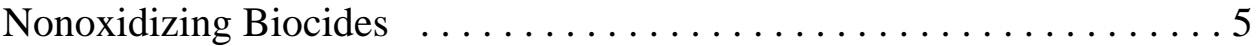

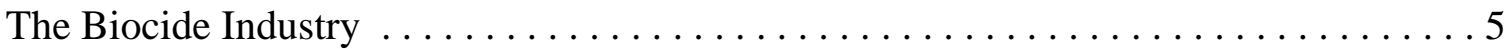

Biocides Actually Used in Power Plant Cooling Towers $\ldots \ldots \ldots \ldots \ldots \ldots \ldots$

Biocides Actually Used in Refinery Cooling Towers $\ldots \ldots \ldots \ldots \ldots \ldots \ldots \ldots 7$

Chapter 3 - Water Quality Requirements Affecting Biocide Usage $\ldots \ldots \ldots \ldots \ldots \ldots . \ldots 9$

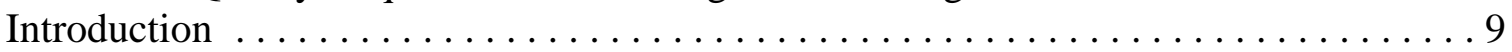

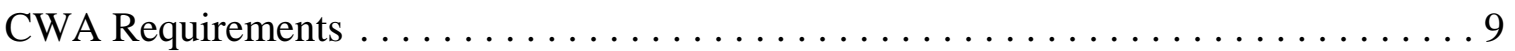

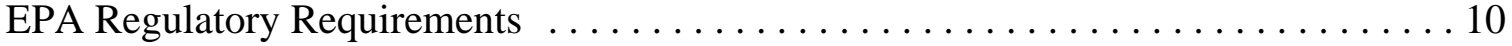

Permit Application ............................... 10

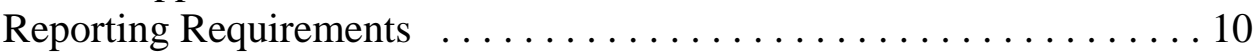

Water Quality-Based Limits $\ldots \ldots \ldots \ldots \ldots \ldots \ldots \ldots \ldots \ldots \ldots$

Best Management Practices .......................... 11

Permit Modification ............................. 11

Steam Electric Power Effluent Limitations Guidelines . . . . . . . . . 11

Petroleum Refining Effluent Limitations Guidelines ........... 12

Great Lakes Water Quality Guidance $\ldots \ldots \ldots \ldots \ldots \ldots \ldots \ldots \ldots 12$

State Regulatory Requirements $\ldots \ldots \ldots \ldots \ldots \ldots \ldots \ldots \ldots \ldots \ldots \ldots \ldots$

Chapter 4 - Interactions with Regulators on Biocide Discharges $\ldots \ldots \ldots \ldots \ldots \ldots \ldots$

Procedure for Obtaining Approval to Discharge Biocides $\ldots \ldots \ldots \ldots \ldots \ldots \ldots \ldots$

Types of Permit Limits and Controls ........................... 16

Operational Practices to Meet Permit Limits on Biocides ................ 16

Ease of Obtaining Approval to Discharge New Biocides $\ldots \ldots \ldots \ldots \ldots \ldots \ldots 17$

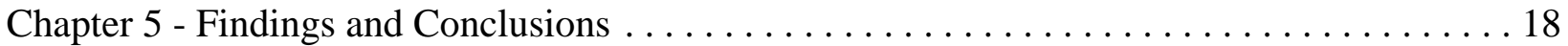

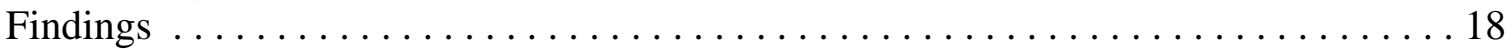

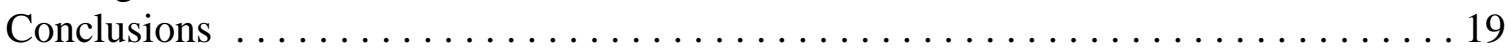

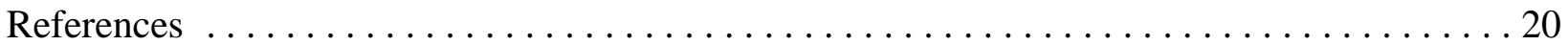




\section{Tables}

Table 1 - Information on Biocide Usage in Power Plant Cooling Towers

Table 2 - Distribution of Power Plants Providing Data on Biocide Usage

Table 3 - Distribution of U.S. Power Plants Using Cooling Towers for Main Condenser Cooling

Table 4 - Frequency of Usage of Different Types of Biocides at Power Plants

Table 5 - Frequency of Usage of Biocide Combinations at Power Plants

Table 6 - Information on Biocide Usage in Refinery Cooling Towers

Table 7 - Frequency of Usage of Different Types of Biocides at Refineries

\section{Figures}

Figure 1 - EPA Regions 


\section{Notation Summary}

BAT best available technology economically achievable

bbl barrel

BCC bioaccumulative chemical of concern

BCF bioconcentration factor

BCDMH 1-bromo, 3-chloro, 5,5-dimethylhydantoin

BCT best conventional technology

CFR Code of Federal Regulations

CWA Clean Water Act

DBNPA dibromonitrilopropionamide

DEP

DGH

(Pennsylvania) Department of Environmental Protection

DOE

EC50

dodecyl guanidine hydrochloride

EEI

ELGs

EPA

U.S. Department of Energy

median effect concentration

Edison Electric Institute

effluent limitations guidelines

EPRI

U.S. Environmental Protection Agency

FAC

Electric Power Research Institute

FAO

free available chlorine

FIFRA Federal Insecticide, Fungicide, and Rodenticide Act

$\mathrm{HOBr}$ hypobromous acid

HOCl hypochlorous acid

HQW high-quality waters

LC50 median lethal concentration

MBT methylene bis-thiocyanate

MSDS material safety data sheet

MW megawatt

NPDES National Pollutant Discharge Elimination System

NSPS new source performance standards

ORW outstanding resource waters

Quat quaternary ammonium salt

SWS sensitive public and private water supplies

TLM median tolerance limit

TRC total residual chlorine

TRH total residual halogens

TRO total residual oxidants

WET whole effluent toxicity

WQB water quality-based (limits)

ZID zone of initial dilution 


\section{Biocide Usage in Cooling Towers in the Electric Power and Petroleum Refining Industries by John Veil, James Rice, and Mary Raivel}

\section{Executive Summary}

Cooling tower users frequently apply biocides to the circulating cooling water to control growth of microorganisms, algae, and macroorganisms. Because of the toxic properties of biocides, there is a potential for the regulatory controls on their use and discharge to become increasingly more stringent. This report examines the types of biocides used in cooling towers by companies in the electric power and petroleum refining industries, and the experiences those companies have had in dealing with agencies that regulate cooling tower blowdown discharges.

Results from a sample of 67 electric power plants indicate that the use of oxidizing biocides (particularly chlorine) is favored. Quaternary ammonia salts (quats), a type of nonoxidizing biocide, are also used in many power plant cooling towers. Little information is available about biocide usage in refineries. Results from a sample of 15 refineries indicate that oxidizing biocides (chlorine and bromine) are commonly used. Moreover, nonoxidizing biocides (particularly isothiazoline, glutaraldehyde, and quats) are used more often in refinery cooling towers than power plant cooling towers.

The experience of dealing with regulators to obtain approval to discharge biocides differs significantly between the two industries. In the electric power industry, discharges of any new biocide typically must be approved in writing by the regulatory agency. The approval process for refineries is less formal. In most cases, the refinery must notify the regulatory agency that it is planning to use a new biocide, but the refinery does not need to get written approval before using it.

Depending on the state in which a power plant is located, permit limits on oxidizing biocides may be technology-based (determined by the U.S. Environmental Protection Agency's effluent limitations guidelines) or water quality-based (based on a state's water quality standards). Some permits contain both types of limits. In refineries, few limits are placed on biocides. One reason for this is that refinery blowdown is not discharged directly to receiving waters but is first sent to a plantwide wastewater treatment plant or equalization pond.

Plant operators use various operational procedures to minimize the concentration of biocides that are discharged. These procedures include closing the blowdown valve before biocides are added to allow time for their dissipation, adsorbing quats on bentonite or fly ash, discharging blowdown to large sediment or retention ponds, and dechlorination.

The conclusion of the report is that few of the surveyed facilities are having any difficulty in using and discharging the biocides they want to use. 


\section{Chapter 1 - Introduction}

Purpose

Biocides are used in many cooling water systems to prevent the buildup of microorganisms that can impede heat transfer across heat exchanging surfaces. Biocides are also used to prevent excessive algal or macroorganism growth, which can block pipes, tubing, and other water conveyances, thereby leading to insufficient cooling water flow. Because of the toxic properties of biocides, there is the potential for the regulatory controls on their use to become increasingly stringent. The U.S. Department of Energy (DOE), as part of its efforts to ensure an adequate, affordable supply of energy for the United States, tries to identify regulatory barriers that add to energy costs. The purpose of this report is to determine if the current regulatory framework has created any unnecessary barriers that prevent cooling water users from selecting the biocides they would most like to use, thereby increasing the cost of electricity or petroleum products.

This report evaluates the types of biocides that are added to cooling towers at electric power plants and petroleum refineries. Federal and state requirements for discharging wastewater containing biocides are examined to determine if there are any regulatory barriers that prevent the use of the most desirable biocides. The report also summarizes the results of interviews with representatives of electric power companies and refineries about their experiences in getting approval from regulatory agencies to use new or different biocides in their cooling towers.

\section{Cooling Water Systems}

Water is used in many industrial applications for cooling machinery or condensing steam. The two types of water-based cooling systems are once-through cooling and closed-cycle cooling. Once-through cooling systems withdraw large volumes of water from a river, lake, estuary, or ocean; pump the water through condensers or heat exchangers; and return it to the same or a nearby body of water. Closed-cycle cooling systems rely on a cooling tower, cooling pond, or cooling lake. Water is withdrawn from the cooling tower basin, lake, or pond; pumped to the condenser or heat exchanger; and then returned to the basin, lake, or pond. Some power plants operate cooling towers (helper towers) in conjunction with once-through cooling systems. Other plants may switch from once-through to helper towers to full closed-cycle operation and back again seasonally (Bodensteiner 1997).

The largest industrial user of cooling water is the electric power industry. Typically, the process of generating electricity involves using a nuclear or fossil fuel energy source to heat purified water to create steam. The steam is used to drive turbines, which, in turn, drive generators. The generators produce electricity. After it leaves the turbines, the steam passes through a condenser that has multiple tubes and a large surface area. Cooling water circulates through the tubes and condenses the steam while raising the temperature of the cooling water.

In the 1996 edition of its Environmental Directory of U.S. Power Plants, the Edison Electric 
Institute (EEI) summarizes the U.S. installed generating capacity in megawatts (MW) by type of cooling water system (EEI 1996). Once-through systems are used for $44 \%$ of capacity (258,906 MW). Closed-cycle systems account for 50\% of capacity; cooling towers - 35\% (206,605 MW), and cooling lakes or ponds - $15 \%(85,502 \mathrm{MW})$. The total U.S. steam electric generating capacity reported by EEI (1996) is 584,328 MW.

Refineries also use a large amount of cooling water. Product heat exchangers and condensers are used for cooling as part of the distillation and cracking processes. In the past, many refinery exhaust steam systems used once-through barometric condensers that produced a large volume of contaminated cooling water. Most refineries have now switched to closed-cycle cooling tower systems that use recycled, noncontact cooling water. According to the U.S. Environmental Protection Agency (EPA 1996), cooling tower blowdown can contribute up to one-third of total refinery wastewater.

We could find no references that provided a national perspective on the percentage of different types of cooling water systems used at refineries. The EPA (1996) indicates that many refineries have converted from once-through cooling systems to cooling towers but does not provide data to quantify that statement.

\section{Cooling Towers}

Although biocides are used in once-through systems and in cooling ponds and lakes, this report focuses only on biocide usage in cooling towers. In a typical cooling tower, hot water from a condenser or heat exchanger is pumped to the top of the fill material in the tower, where it spreads into a thin layer. The hot water then falls to the bottom of the tower. While the water is moving down, it comes into contact with air moving up, and some of the heat in the water is transferred to the air through evaporation. At facilities with small to medium cooling requirements, mechanical draft towers are prevalent. They rely on fans to draw air upward. At facilities with very large cooling requirements, natural draft towers may be used. These tall, parabolic-shaped concrete structures naturally create an upward-moving air current. The cooled water returns to the recirculating system, and the heated and moisture-laden air exits through the top of the tower.

In cooling towers, water is lost through evaporation and must be replaced with makeup water. Also, dissolved constituents become concentrated through evaporation. To avoid excessive concentrations of certain constituents, part of the recirculating water is removed as blowdown. The blowdown waste stream contains concentrated matter from the makeup water as well as residual concentrations of biocides, potential process contamination, and any other chemicals added for corrosion or deposit control. Regulatory agencies often place numerical limits on biocides in cooling tower blowdown discharges. More information on regulatory requirements is presented in Chapter 3. 


\section{Chapter 2 - Biocides}

Background

Various treatment chemicals are added to cooling water systems to prevent scaling and corrosion of structural and heat transfer surfaces. These chemicals are not the subject of this report and therefore are not discussed further. Other chemicals called biocides are added to control the biological growth that can impede cooling water flow or reduce heat transfer efficiency. This chapter provides an overview of the types of biocides that are generally used in industrial cooling water systems, emphasizing those that are used most commonly in the electric power and refinery industries. Information on the types of biocides used was collected by interviewing water treatment consultants, personnel at companies that manufacture or formulate biocides, and personnel who are responsible for water treatment at utilities and refineries.

Products are selected on the basis of cost, the chemistry of the water being treated, and the organisms that need to be controlled. Reports prepared by the major biocide suppliers provide information on the advantages and disadvantages of different types of biocides (for example, see Soukup [1996] and Lutey [1996]).

Biocides can be grouped into two general categories, oxidizing and nonoxidizing, depending on the mechanism used to kill target organisms. Oxidizing biocides are more widely used in the electric power and refining industries because of their effectiveness, moderate cost, easy treatability, and the users' familiarity with them.

Oxidizing Biocides - Most oxidizing biocides are chlorine or bromine compounds. When added to water, they form hypochlorous acid $(\mathrm{HOCl})$ or hypobromous acid $(\mathrm{HOBr})$, which act as the active ingredient. Historically, chlorine gas was widely used because of its low cost. However, in recent years, many users have switched to other forms of chlorine because of the health and safety risks associated with handling chlorine gas. Bleach (sodium hypochlorite) is now widely used as a source of HOCl. Chlorine dioxide has not been used much in the electric power and refining industries. Chloroisocyanurates are another form of chlorine biocide that have not been used much in these industries.

Sources of $\mathrm{HOBr}$ are becoming increasingly popular in place of or in addition to sources of HOCl. Sodium bromide is often added along with bleach. The sodium bromide reacts with the $\mathrm{HOCl}$ to form $\mathrm{HOBr}$, which is an effective microbiocide over a wider $\mathrm{pH}$ range than is $\mathrm{HOCl}$. Another biocide, 1-bromo, 3-chloro, 5,5-dimethylhydantoin (BCDMH), serves as a chlorine and bromine donor and can generate $\mathrm{HOBr}$.

Other oxidizing biocides that do not rely on chlorine or bromine as an active agent include ozone and hydrogen peroxide. Neither of these products is used much in the U.S. electric power or refining industries but ozone is popular in Europe.

Nonoxidizing Biocides - Numerous nonoxidizing chemicals have been used as either 
primary biocides or as supplements to oxidizing biocide applications. One product that is widely used in the electric power industry for control of zebra mussels and other organisms is quaternary ammonium salts (quats). Some other nonoxidizing biocides used include glutaraldehyde, isothiazoline, triazine, organo-tin compounds, dodecylguanidine hydrochloride (DGH), carbamates, methylene bis-thiocyanate (MBT), and dibromonitrilopropionamide (DBNPA).

Three experts in the water treatment field indicated that although oxidizing biocides are used more heavily in cooling towers in the electric power and refining industries, some nonoxidizing biocides are used. They were interviewed to gain a better perspective on which nonoxidizing biocides are most commonly used. Paul Puckorius indicated that utilities use some quats in intake lines to prevent zebra mussel fouling and some triazine in cooling towers to control algae. He suggested that in refineries, glutaraldehyde and isothiazoline are used most, and triazine, DBNPA, and MBT are used to some extent as well. ${ }^{1}$

Another expert, Dan Robinette, provided a similar perspective, noting that glutaraldehyde and isothiazoline are used more than some of the other products. He suggested that refineries are more likely than power plants to use nonoxidizing biocides because the nonoxidizing biocides cost more and because refineries have less water that requires treatment. ${ }^{2}$

Rudy Thorgeson indicated that power plants primarily use quats as nonoxidizing biocides. Refineries supplement oxidizing biocides with nonoxidizing products because the hydrocarbons in refinery cooling water systems may negate the effect of oxidizing biocides. Refineries use isothiazoline, glutaraldehyde, quats, MBT, and triazine. ${ }^{3}$

\section{The Biocide Industry}

Note: mention of or reference to any biocide manufacturer, supplier, or product in this report does not constitute an endorsement or recommendation but is intended solely to provide clarification.

The first tier of the biocide industry consists of the manufacturers of the active ingredients. Some of the oxidizing biocides are simple solutions of common chemicals like bleach. End users can purchase these products, as well as chlorine gas, directly from the manufacturer. The second tier of the industry is made up of biocide suppliers that sell ready-to-use biocides made by mixing the active ingredients with other additives or carrier fluids. In many cases, their products are proprietary mixtures that are given commercial names rather than chemical names (e.g., Betz CT-2

\footnotetext{
${ }^{1}$ Personal communication between P. R. Puckorius, Puckorius \& Associates, Inc., Evergreen, Colo., and J. Veil, Argonne National Laboratory, Washington, D.C., on October 23, 1996.

${ }^{2}$ Personal communication between D. Robinette, Puckorius \& Associates, Inc., Evergreen, Colo., and J. Veil, Argonne National Laboratory, Washington, D.C., on July 31, 1996.

${ }^{3}$ Personal communication between R. Thorgeson, Trident Chemicals, Baton Rouge, La., and J. Veil, Argonne National Laboratory, Washington, D.C. on July 31, 1996.
} 
rather than quat or Calgon H-900 rather than BCDMH). Most of these second-tier companies not only sell biocides but also provide full water treatment services to users. The range of services provided includes chemical analysis of the water to be treated, assistance in getting regulatory approval to use the product, dosing recommendations, and actual operation of the water treatment system, if desired. In some cases, manufacturers may also serve as suppliers. The third tier of the industry is made up of independent consultants who provide a full range of water treatment services to users but do not sell or provide any biocide products.

\section{Biocides Actually Used in Power Plant Cooling Towers}

This section describes information collected directly from the utilities about the biocides they use. EEI (1996) provides information on each U.S. power plant's cooling water system and generating capacity. We used this information to contact each power company that operates at least one cooling tower plant that generates 1,000 MW or more of electricity. We also contacted several other power companies with which we have worked on previous projects. Many but not all of them responded to our inquiries. We collected data from 38 utilities representing 67 power plants. The plants that responded to the study collectively generate 101,911 MW, about half of the total U.S. generating capacity operating with cooling towers. Most of the U.S. plants not included in this study that operate with cooling towers are presumed to also use biocides, although this study does not provide any information on the types of biocides the plants actually use. We entered information on the types of biocides that are used by each plant into a database. These data are presented in Table 1, which is broken down by EPA region and state. Figure 1, reprinted from EPA (1990), shows which states are included in each of the EPA regions.

Table 2 shows the distribution of plants contained in this database. Regions 3, 4, and 5 each contributed between 22\% and 31\% of the total number of plants and the total amount of power generated (MW) represented in the study. Plants in Region 1 or 8 did not provide any data. Regions 2, 6, 7, 9, and 10 combined made up $20 \%$ of the plants and $10 \%$ of the generated power represented in the study. This distribution reasonably approximates the distribution of all U.S. power plants that use cooling towers. Table 3, prepared from data taken from EEI (1996), shows that plants in Regions $3,4,5$, and 6 combined generated nearly $75 \%$ of the total power generated at U.S. plants that use cooling towers. The remaining six regions generated a smaller percentage of the total electricity generated by plants that use cooling towers.

Table 4 shows the types of biocides that are used in the cooling towers at the surveyed plants. The most common biocide by far is chlorine, which is used at 53 of 67 plants. (In this study, the term "chlorine" refers to either chlorine gas or sodium hypochlorite; most plants now use sodium hypochlorite as the chlorine source.) The oxidizing biocides bromine, BCDMH, and chlorine dioxide are used at 18 plants, 3 plants, and 1 plant, respectively. Among the nonoxidizing biocides, quats are used at 28 plants, DGH is used at three plants, and triazine is used at one plant.

Seven of the plants surveyed do not use any biocides. At six of these plants, no biocides are used in the cooling towers and in the seventh plant, no blowdown is discharged to surface waters. Thirty-three plants use only oxidizing biocides, six use only nonoxidizing biocides, and the 
remaining 21 plants use a combination of both types of biocides.

Many cooling tower operators use more than one biocide product. Table 5 shows the most common products used, either individually or in combination, at the 67 plants. At 22 plants, chlorine is used by itself, and at 11 other plants, it is used with bromine. Chlorine is used with quats at 10 plants, and at 10 other plants, chlorine, bromine, and quats are used in combination. Three plants use just quats. Seven plants use no biocides. The remaining 4 plants use some other biocide or combination of biocides.

These data indicate that most of the utilities surveyed use oxidizing biocides as their main biocidal agent. About $40 \%$ of the surveyed plants use quats, either as the sole biocide or in combination with another biocide. Few plants use the other types of nonoxidizing biocides.

The biocide information reported above refers to cooling towers that cool main condenser water. Some plants operate separate and much smaller cooling towers that cool plant service water. We collected only limited information on the use of biocides in service water cooling towers, but these data indicate that utilities may use more nonoxidizing biocides in the smaller towers than the main cooling towers.

\section{Biocides Actually Used in Refinery Cooling Towers}

This report previously presented data on the types of biocides that water treatment experts expected to be used in cooling towers at refineries. Apparently no centralized information base on the use of cooling water in refineries exists. Collecting data on the type of cooling systems and biocides used at refineries was quite difficult. Although most electric utility companies were willing to share information about their biocide usage with us, the majority of refinery personnel contacted did not provide any information. The refining industry's limited response may reflect the fact that cooling water is a relatively minor effluent stream at refineries that does not require significant attention from a treatment standpoint. Given the full range of environmental issues faced by refineries, cooling water carries a relatively low priority. In addition, the refineries' reluctance to participate in the survey may be attributable to a concern that information about biocide usage could be used by competitors to gain a competitive advantage or by regulators to increase controls on biocide usage.

We collected biocide usage information for 15 refineries, representing 2,718,400 barrels per day (bbl/day) of atmospheric crude oil distillation capacity. This number is only a small percentage of the U.S. total of 159 refineries and 15,081,680 bbl/day (DOE 1995). Five of the refineries are located in Washington state. The reason for this heavy representation in just one state is that the Washington state coordinator for the Western States Petroleum Association was very helpful in

providing contacts for his member refineries. The remaining 10 refineries are scattered throughout nine states.

Table 6 identifies the surveyed refineries and the biocides they use. Table 7 summarizes the 
frequency at which different biocides are used. Chlorine is used at 10 refineries, and bromine is used at seven. Other types of oxidizing biocides - BCDMH and chlorine dioxide - are used at one refinery each. Among the nonoxidizing biocides, isothiazoline is used at five refineries, gluteraldehyde is used at four, and quats are used at three. DGH and MBT are used at one refinery each.

Table 5 indicates that many power plants use just one type of biocide. The limited refinery data in Table 6 indicate that only 2 of 15 plants use a single biocide, 8 plants use two biocides in combination, and 5 plants use three different biocides. The use of multiple biocides most likely results from the complex and variable nature of the contaminants that enter the cooling water as process material leaks into it. 


\section{Chapter 3 - Water Quality Requirements Affecting Biocide Usage}

\section{$\underline{\text { Introduction }}$}

Several federal programs may play a role in a company's choice of biocides. First, the federal Insecticide, Fungicide, and Rodenticide Act (FIFRA) and its implementing regulations require registration of all pesticides (including biocides) sold or used in the United States. FIFRA controls the ability of companies to distribute and use biocide products but does not control the discharge of wastewater streams containing biocides. Regulation of wastewater containing biocides falls under the jurisdiction of the Clean Water Act (CWA). Because of the narrow focus of this report, it reviews only the effect of water quality and water pollution controls on a company's ability to discharge, and thereby to use, biocides. The report contains no further discussion of FIFRA rules and regulations.

EPA's Toxic Release Inventory (TRI) program also applies to releases of chlorine from power plants and refineries. The TRI program requires reporting of releases but does not place regulatory controls on the releases. Therefore the report contains no further discussion of TRI rules and regulations.

The Clean Air Act authorizes EPA programs for air emissions from industrial sources. Emissions from cooling towers may contain particulates as well as some toxic chemicals. Plant operators may need to obtain various air quality permits in order to construct and operate cooling towers. Because this report focuses solely on water quality constraints, no further discussion of Clean Air Act rules or regulations is made in this report.

\section{$\underline{\text { CWA Requirements }}$}

The CWA provides the federal statutory basis for most water quality and water pollution control programs. The opening section of the CWA lists goals and policies, including §101(a)(3), which states: "it is the national policy that the discharge of toxic pollutants in toxic amounts be prohibited.” This policy drives EPA regulations concerning the discharge of toxic materials such as biocides.

CWA §402 establishes the National Pollutant Discharge Elimination System (NPDES), which requires that all point source discharges of pollutants to surface waters must be authorized by NPDES discharge permits. Limits in NPDES permits can be technology-based or water qualitybased. For most major industrial categories, including both the steam electric power and petroleum refining categories, the EPA is directed to develop effluent limitations guidelines (ELGs) that establish national minimum discharge standards [§304(b) and §306]. For existing facilities, the applicable level of performance is known as best available technology economically achievable (BAT) or best conventional technology (BCT) [both from §301], and for new facilities, it is known as new source performance standards (NSPS) [§306]. In the absence of BAT, BCT, or NSPS standards, permit writers must use their best professional judgment to set a technology-based limit $[\S 402(\mathrm{a})(1)(\mathrm{B})]$. 
If a technology-based limit is determined to be insufficient to achieve water quality standards outside a mixing zone, ${ }^{4}$ stricter limits that are based on a state's water quality standards must be imposed (§302). States are directed to develop and adopt water quality standards, and, if they fail to do so, the EPA must adopt standards for them [§303].

The CWA anticipates that states will seek and be delegated authority to administer the NPDES program. More than 40 states have been so delegated. Therefore, in most states, NPDES permits are issued by state regulatory agencies. In states that have not been delegated to administer the NPDES program, the EPA regional office issues NPDES permits.

\section{EPA Regulatory Requirements}

The EPA has published lengthy regulations for implementing the NPDES program. Rather than reiterate the full set of regulations, this section highlights portions of the regulations that are relevant to the use of biocides and the discharge of cooling tower blowdown that contains biocides. All regulations identified in this section are from Title 40 of the Code of Federal Regulations (CFR).

Permit Application: Part 122.21 (g) outlines the application requirements for existing industrial dischargers. Of particular note is subsection (g)(7), which specifies the information on effluent characteristics that must be submitted. Dischargers in the steam electric power and petroleum refining industries must submit quantitative data on the concentrations of any pollutants that are listed in several tables of Appendix 4 to Part 122. Of all the pollutants in these tables, only total residual chlorine is a component of the biocides discussed in the previous chapter. Subsection (g)(9) requires dischargers to submit a list of any toxic pollutants that are used or manufactured as an intermediate or final product or by-product.

While not directly applicable to cooling tower blowdown from power plants and refineries, another section of the application requirements clearly states the EPA's interest in cooling water additives, including biocides. Part 122.21 (h) outlines application requirements for industrial facilities that discharge only nonprocess wastewater. Subsection (h)(3) requires dischargers to identify any cooling water additives that are used or expected to be used, along with their composition.

Reporting Requirements: Part 122.42 (a) requires permittees to notify the EPA or a delegated state agency if any activity has occurred or will occur that would result in the discharge of any toxic pollutant not limited in the permit, if that discharge will exceed any of the listed notification levels. Several notification levels are specified, but for biocide usage, only two levels are relevant. The notification level for activities that have occurred or will occur on a routine or frequent basis (e.g., switching to a new biocide) is $0.1 \mathrm{mg} / \mathrm{L}$, and the level for activities that have

\footnotetext{
${ }^{4}$ A mixing zone is an area around the discharge point that allows for initial dilution and mixing of the effluent. The size and shape of the mixing zone is typically defined by state regulation. Within mixing zones, water quality criteria can be exceeded.
} 
occurred or will

occur on a nonroutine or infrequent basis (e.g., adding a specialized biocide once or twice per year for molluscicide control) is $0.5 \mathrm{mg} / \mathrm{L}$.

Water Quality-Based Limits: Part 122.44(d) describes permit limits and conditions. Paragraph (d)(1)(I) specifies that permits must contain water quality-based limits if the permitting agency determines that any discharge of the pollutant will cause, have the reasonable potential to cause, or contribute to an excursion above a state numeric or narrative water quality standard. Narrative standards are important in that they provide a means of protection from pollutants for which a state has not adopted a numeric standard. Paragraph (d)(1)(v) states that when a discharge causes, has the reasonable potential to cause, or contributes to an instream violation of a narrative water quality standard, permits must contain whole effluent toxicity (WET) limits unless the permitting agency demonstrates that chemical-specific limits are sufficient to attain and maintain water quality standards.

Paragraph (d)(1)(vi) directs the permitting agency to establish effluent limits for a pollutant for which a state has no numeric water quality standard when this pollutant is present at a level that causes, has the reasonable potential to cause, or contributes to a violation of a narrative water quality standard. In such a case, the limits can be set by (a) calculating a numeric criterion through state regulation or policy, (b) using an EPA water quality criterion, or (c) placing limits on an indicator parameter.

Best Management Practices: Section $122.44(\mathrm{k})$ allows the permitting agency to require best management practices in lieu of or in addition to numeric limits. An example of a best management practice is a condition in a permit that requires cooling tower blowdown containing a quat-based molluscicide to be treated by addition of bentonite to detoxify the quat.

Permit Modification: Section 122.62 (a) outlines the causes for permit modification. The cause most relevant to biocide usage is contained in subsection (a)(2), which allows for modification if the permitting agency receives information that was not available at the time of the original permit application (e.g., a request to use a new or different biocide product).

Steam Electric Power Effluent Limitations Guidelines: Part 423 contains technologybased discharge standards for power plants. Numerical limits are provided for several waste streams. Sections 423.13 (d) and 423.15 (j) outline the limits for cooling tower blowdown. Free available chlorine is limited to an average level of $0.2 \mathrm{mg} / \mathrm{L}$ and a maximum level of $0.5 \mathrm{mg} / \mathrm{L}$. None of the 129 priority pollutants (listed as Appendix A to Part 423) except chromium and zinc may be discharged. Total chromium is limited to an average and maximum level of $0.2 \mathrm{mg} / \mathrm{L}$ and total zinc is limited to an average and maximum level of $1.0 \mathrm{mg} / \mathrm{L}$. Neither free available chlorine nor total residual chlorine may be discharged from any unit for more than two hours in any one day, and not more than one unit in any plant may discharge free available or total residual chlorine at any one time unless the utility can demonstrate to the regulatory agency that the units cannot operate at or below this level of chlorination. Blowdown is also subject to a pH range limit of 6.0-9.0. 
Because some cooling towers may be operated in helper mode and discharge to once-through cooling systems, we also note the chlorine limit for once-through discharges of $0.20 \mathrm{mg} / \mathrm{L}$ maximum expressed as total residual chlorine [423.13 (b) and 423.15 (h)]. Total residual chlorine may not be discharged from any single generating unit for more than two hours per day unless the utility can demonstrate to the permitting authority that discharge for more than two hours per day is required for macroinvertebrate control. Simultaneous multi-unit chlorination is permitted.

Petroleum Refining Effluent Limitations Guidelines: Part 419 contains technology-based standards for refineries. Whereas the steam electric power effluent guidelines are organized by waste stream, the petroleum refining effluent guidelines are organized by production process: topping, cracking, petrochemical, lube, and integrated. Refineries typically pipe most or all waste streams to a central wastewater treatment plant. Part 419 contains no limits specific to cooling towers, although cooling tower blowdown is one of the waste streams that flows to the treatment plant. For all five subcategories, limits are placed on biochemical oxygen demand, total suspended solids, oil and grease, $\mathrm{pH}$, chemical oxygen demand, phenolic compounds, total chromium, hexavalent chromium, ammonia, sulfide, and total organic carbon.

Great Lakes Water Quality Guidance: Perhaps the most comprehensive set of water quality regulations ever promulgated was adopted by the EPA in March 1995. Part 132 establishes a new program of water quality guidance applicable to all waters within the Great Lakes basin. The guidance includes numeric criteria for specified pollutants to protect aquatic life, wildlife, and human health; methodologies to derive numeric criteria for other pollutants; procedures for translating proposed water quality criteria into enforceable controls; and a policy of antidegradation.

Part 132.3 directs Great Lakes States to adopt numeric criteria consistent with the pollutants listed in Tables 1-4 of Part 132. The chemicals listed in those tables are bioaccumulative chemicals of concern (BCCs), which are pollutants that were selected because they are particularly persistent or bioaccumulative. None of the biocides discussed in the previous chapter contain BCCs. Therefore Part 132.3 has little impact on biocide usage.

Part 132.4 directs Great Lakes States to adopt requirements that are consistent with those contained in the appendixes to Part 132. Appendixes A, C, and D establish methodologies for adopting numeric criteria for those pollutants other than BCCs (except for pollutants listed in Table 5 to Part 132, which are exempted). Although chlorine is exempted because it is listed in Table 5, the use of other biocides potentially could be affected if a state adopts criteria for the toxic components of biocides. For example, if a state adopts criteria for isothiazoline or quats, use of those biocides could be restricted. The Great Lakes States are just beginning to submit revised water quality regulations. No information is currently available on how the revised state regulations might affect biocide usage.

Appendix E to Part 132 outlines antidegradation requirements that describe what must be satisfied before approving requests to discharge new pollutants or increased levels of pollutants. The minimum requirements apply only to BCCs. Therefore, biocide usage should not be affected 
by the

minimum requirements. However, states may elect to be more restrictive than the minimum requirements.

Appendix F to Part 132 specifies procedures for implementing the Great Lakes Water Quality Guidance in NPDES permits. The implementation procedures are applicable to those pollutants for which a state has adopted water quality criteria. With the exception of chlorine, which is already exempted from the requirements of Appendix F, states are unlikely to establish water quality criteria for the active ingredients in biocides, since those chemicals are not BCCs, not found in Table 6 to Part 132, and not discharged in large quantities.

Procedure 6 in Appendix F specifies that states must adopt numeric criteria for WET. If a permitting agency determines that an effluent will cause, have the potential to cause, or contribute to an excursion above any numeric WET criterion, the agency may establish water quality-based limits for WET. Many power plant and refinery permits already contain WET limits or monitoring requirements, but this regulation could potentially lead to stricter WET limits. However, until all Great Lakes States adopt regulations implementing the Great Lakes Water Quality Guidance, it is impossible to tell whether those regulations will affect biocide usage.

\section{$\underline{\text { State Regulatory Requirements }}$}

States have the authority to promulgate additional effluent discharge and water quality regulations pertaining to areas not covered by the federal regulations and to promulgate regulations that are stricter than federal regulations. To get a sense of the range of additional regulatory requirements imposed by state agencies, we reviewed and analyzed the water quality regulations of twelve states: Florida, Georgia, Indiana, New Mexico, Ohio, Oklahoma, Pennsylvania, Texas, Washington, West Virginia, Wisconsin, and Wyoming. These states were selected to represent different regions of the country where cooling towers are used. Our analysis identified additional requirements applicable to the usage and discharge of biocides beyond those contained in the federal regulations. Appendix A identifies specific state regulations applicable to the discharge of biocides that go beyond the federal regulations, and it contains detailed summaries of those regulations. A number of these additional state regulations contain requirements specific to biocides. The biocidespecific requirements include narrative and numeric water quality criteria, which, in many cases, are specific to individual classes of water. They also contain water quality-based effluent limitations for biocides, and they describe methods for establishing these effluent limitations.

In addition to the biocide-specific regulations, these states have promulgated other regulations with requirements, beyond the federal requirements, applicable to discharges of effluents containing biocides. Some of these regulations are for water quality standards and water qualitybased effluent limitations and pertain to toxic substances. The water quality standards regulations contain requirements for determining acute and chronic toxicity criteria on the basis of the classification of a water body and the availability of data. There are also requirements concerning the application of water quality standards. The regulations concerning water quality-based effluent 
limitations describe methods for determining the necessity for these effluent limitations, contain narrative criteria, describe methods for establishing numeric water quality-based effluent limitations and waste load allocations, and list safe concentration values.

Other relevant state regulations that go beyond the federal requirements are those pertaining to permit application requirements, mixing zones, and whole effluent toxicity testing. The permit application requirements apply to new and increased discharges of biocides, and they contain exclusions and waivers. Most of the mixing zone regulations prohibit exceedance of acute toxicity levels in mixing zones, except in small zones of initial dilution. Some, however, prohibit exceedance of acute toxicity anywhere in the mixing zone. A few states have mixing zone requirements specific to individual classes of water bodies, and some include effluent limitations specific to mixing zones. The WET regulations identify methods for determining the necessity for WET testing, rules of general application, and exclusions. 


\section{Chapter 4 - Interactions with Regulators on Biocide Discharges}

Procedure for Obtaining Approval to Discharge Biocides

Applications for NPDES permits should contain information about the types of biocides that are currently being used or are expected to be used. Regulatory agencies may also request supporting information such as dosage rates and frequencies, aquatic toxicity data, and material safety data sheets (MSDSs). The supporting information is generally provided by a biocide supplier to the user or, at the user's request, directly to the regulatory agency. Permit writers evaluate the submitted information and determine which biocides to approve. For power plants, the permit generally authorizes the discharge of particular biocides by name and may include numerical limits or monitoring requirements. In some cases, the permit may also include operational requirements.

NPDES permits are typically issued for a term of five years. Before the permit expires, it is not uncommon for a discharger to decide to change or use additional new biocides that have not been approved in the permit. The procedures for obtaining approval to discharge new biocides vary widely. The procedures used by power plants are outlined in Table 1 . No utility reported that it could discharge different or new biocides without getting some type of formal approval. Many of the plants surveyed did not report on the nature of the approval process; however, 18 plants stated that changes could be handled through letter approval, while 7 plants reported that they needed to obtain a permit modification. Four plants reported that they would need letter approval to change a supplier or the form of the active ingredient but would need a permit modification to make any change in the active ingredient itself. Two other plants were not sure which mechanism would be required. One plant indicated that it needs to get a separate approval for each annual application of quats.

Information on the approval process used by the surveyed refineries is found in Table 6 . The approval process for refineries appears to be much less rigorous than that for power plants. This is not surprising, since cooling tower blowdowns at refineries have much smaller volumes than do blowdowns at power plants. Refinery blowdowns are sent to a treatment plant, where they are mixed with other waste streams and treated before discharge. Most power plant blowdowns, however, are discharged directly to the receiving waters without further treatment.

A contact person at one refinery that was surveyed indicated that there was no need to notify the regulatory agency that a new product was being used. In nine other cases, the refinery needed to notify the regulatory agency of the new product, but no formal approval was required. One of these nine refineries was required to test for the new biocides four times during the next permit period. One other refinery reported that an approval letter was needed before a new biocide could be used. The remaining four refineries did not discuss the approval procedure they used.

Types of Permit Limits and Controls 
As reported in Chapter 2, chlorine is, by far, the most commonly used biocide. Bromine and other oxidizing biocides are also widely used in power plants. Most NPDES permits for power plants contain numerical limits on a form of chlorine or oxidants. These limits may be expressed as free available chlorine (FAC), total residual chlorine (TRC), free available oxidants (FAO), total residual oxidants (TRO), or total residual halogens (TRH). Thirty plants had chlorine or oxidant limits based on the steam electric power effluent limitations guidelines (40 CFR Part 423). Seventeen plants had water quality-based limits on chlorine or oxidants in their permits. Four plants had both effluent limitations guidelines limits and water quality-based limits for chlorine or oxidants in their permits.

Quats are also used commonly in power plant cooling towers. Fifteen plants reported that their permits required that no quats be detected in the discharge. Three plants had water quality-based limits placed on quats, and two other plants had limits on the maximum feed rate for quats. Seven plants reported that no numerical limits were set on quats.

Twelve plants reported that they had WET limits or WET testing requirements in their permits. It is not clear if the WET limits or testing requirements were applied to only the cooling tower blowdown stream or to some other places in the plant. One plant reported that it was required to perform additional WET tests when biocides were being used.

Of the 15 refineries surveyed, two had chlorine limits and four had WET limits. The WET limits applied to the full discharge from the wastewater treatment plant. No limits were placed on any of the nonoxidizing biocides.

\section{Operational Practices to Meet Permit Limits on Biocides}

Power plants use several primary approaches to meet their permit requirements for biocides. Some actions are specifically required in the permit, like detoxifying quats by using bentonite, but most are voluntary. Many plants close the blowdown valve from the cooling tower system before a biocide is added and leave it closed until the concentration of the pollutant of concern is either below the permitted limit or is nondetectable. Other plants rely on dilution and retention time to reduce the concentration of pollutants. For example, some plants discharge cooling tower blowdown to a settling pond, where any remaining chlorine will dissipate and quats can be adsorbed onto fly ash. Some plants dechlorinate the blowdown to meet limits on chlorine.

Because there are few limits on biocides in refinery permits and refinery blowdowns are treated before discharge, refineries have little incentive to employ special operational practices for biocides. One refinery reported that it closes the blowdown valve until the biocide concentration is sufficiently low before sending the blowdown to the treatment plant. Three refineries reported that they alternate use of three different biocides so that the microorganisms do not develop a tolerance for any one product. 


\section{Ease of Obtaining Approval to Discharge New Biocides}

All surveyed facilities were asked whether they had experienced any difficulty in working with their regulatory agency to get permission to discharge new biocides. The overwhelming majority of facilities that responded suggested that they are not having problems in getting permission to discharge the biocides they want to use.

It appears that most utilities have developed an acceptable working relationship with their regulatory agencies with regard to biocide approval. The approval process does not always move quickly, but if utilities plan in advance, the process usually produces satisfactory results. Utilities are not likely to request permission to discharge new products unless they have some degree of confidence that the products will be approved.

Out of 67 power plants surveyed, only a few noted problems. One plant reported that several years ago, when it was trying to participate in an Electric Power Research Institute research project on biocides, it had some difficulty with the regulatory agency. Some Pennsylvania utilities noted that the Pennsylvania Department of Environmental Protection (DEP) has written guidance on using and discharging chemical additives, and that they were working with the DEP to relax some of the restrictions in the guidance. Several utilities noted that the demonstrations required by the regulatory agencies to gain approval to discharge new biocides were extensive.

One power plant reported that it had previously been denied permission to discharge bromine, but that it is currently satisfied with using chlorine. Several utilities reported that although they did not anticipate that their regulatory agency would deny permission to discharge a biocide, they might find the resulting permit limits and conditions to be so stringent that they would voluntarily withdraw their request.

All 15 surveyed refineries reported no problems in working with the regulatory agencies on biocides. 


\section{Chapter 5 - Findings and Conclusions}

\section{Findings}

- Sixty-seven power plants that operate cooling towers (representing about one-half of the total U.S. generating capacity that uses cooling towers) indicated that the use of oxidizing biocides is more prevalent than the use of nonoxidizing biocides. Chlorine is the most common biocide used. Oxidizing biocides are preferred because of the large volume of water that is treated and because they are less expensive to use than nonoxidizing biocides. Quats, a nonoxidizing biocide, are also used at many power plants, primarily for control of zebra mussels or other mollusks. Several of the surveyed plants do not use any biocides in their cooling towers.

- $\quad$ Little information is available about biocide usage in U.S. refineries. This study's survey efforts were not very fruitful in adding to the national information base on biocide usage at refineries. Fifteen refineries, representing only $18 \%$ of national atmospheric crude oil distillation capacity, responded with information. This small sample of plants indicated that oxidizing biocides, particularly chlorine and bromine, are widely used.

Nonoxidizing biocides, particularly isothiazoline, glutaraldehyde, and quats, are used more often in refineries than in power plant cooling towers.

- $\quad$ The process for obtaining approval to discharge new biocides varies from state to state and differs notably between the two industries studied here. In the electric power industry, discharges of any new biocide typically must be approved in writing by the regulatory agency. Some states are willing to make approvals through letters, while others require formal modifications to the permit. The approval process for refineries is less formal. In most cases, the refinery must notify the regulatory agency that it is planning to use a new biocide but does not need to get written approval before using it.

- $\quad$ Depending on the state in which a power plant is located, permit limits on oxidizing biocides may be technology-based (determined by the EPA's effluent limitations guidelines) or water quality-based (based on a state's water quality standards). Some permits contain both types of limits. When quats are used in power plant cooling towers, most regulatory agencies either require no detectable quats or set a water quality-based limit. WET testing of cooling tower blowdown is required by some permits.

- In refineries, few limits are placed on biocides. One reason is that refinery blowdown may not be discharged directly to receiving waters but is, in some cases, sent to a plantwide wastewater treatment facility.

- $\quad$ Plant operators follow various operational procedures to minimize the concentrations of biocides that are discharged. These procedures include closing the blowdown valve before biocides are added to allow time for the biocides to dissipate, adsorbing quats on 
bentonite or fly ash, discharging to large sediment or retention ponds, and dechlorination.

- $\quad$ The surveyed facilities reported very few problems in obtaining approval from their regulatory agencies for biocide discharges.

\section{$\underline{\text { Conclusions }}$}

- $\quad$ The purpose of this study was to determine if the current regulatory framework is creating any barriers that are keeping cooling water users from selecting the biocides they would most like to use. Information collected from 67 power plants and 15 refineries indicated that few of the surveyed facilities are having any difficulty in using the biocides they want to use. The dischargers in these two industries, the regulatory agencies, and the biocide manufacturers and suppliers seem to have developed a biocide approval process that works effectively.

- $\quad$ The EPA adopted final Great Lakes Water Quality Guidance in 1995. The guidance has the potential to place stricter requirements on any discharge of toxic pollutants to the Great Lakes drainage system. Each Great Lakes state must adopt regulations that implement the federal guidance by spring 1997, although many Great Lakes states have not yet done so. These regulations are not yet in place so it is impossible to determine what impact they will have on biocide usage. 


\section{References}

Bodensteiner, J., 1997, letter from Bodensteiner, Northern States Power Company, Minneapolis, MN, to J. Veil, Argonne National Laboratory, Washington, D.C., providing comments on draft report, August 20.

DOE, 1995, Petroleum Supply Annual 1994, Volume 1, DOE/EIA-0340(94)/1, U.S. Department of Energy, Energy Information Administration, May.

EEI, 1996, Environmental Directory of U.S. Power Plants, Edison Electric Institute, Washington, D.C.

EPA, 1990, Headquarters Telephone Directory - Autumn 1990, U.S. Environmental Protection Agency, Washington, D.C.

EPA, 1996, Preliminary Data Summary for the Petroleum Refining Category, EPA 821-R-96015, U. S. Environmental Protection Agency, Washington, D.C., July.

Lutey, R.W., 1996, Applied Industrial Microbiological Control, revision 3, Buckman Laboratories International, Memphis, Tenn., August 11.

Soukup, T.J., 1996, The Chemistry and Application of Oxidizing Biocides, ChemTreat, Inc., Richmond, Va., June. 
Table 1 - Information on Biocide Usage in Power Plant Cooling Towers

\begin{tabular}{|c|c|c|c|c|c|c|}
\hline Region & Plant & Biocides Used $^{a}$ & Type of Permit Limit ${ }^{b}$ & Operational Practices & Regulatory Experience & Comments \\
\hline 2 & NJ-1 & $\mathrm{Cl}$ & TRO (ELG) & $\begin{array}{l}\text { dechlorination; WET } \\
\text { testing on blowdown }\end{array}$ & $\begin{array}{l}\text { State might not allow a new } \\
\text { product unless a large amount } \\
\text { of data is provided }\end{array}$ & $\begin{array}{l}\text { had some difficulty } \\
\text { several years ago } \\
\text { when they wanted } \\
\text { to do an EPRI pilot } \\
\text { project on biocides }\end{array}$ \\
\hline 2 & NY-1 & $\begin{array}{l}\mathrm{Cl}, \mathrm{Br}, \text { Quat (Betz CT-2 } \\
\text { or Calgon } \mathrm{H}-130 \mathrm{M})\end{array}$ & $\begin{array}{l}\mathrm{Cl}(\mathrm{ELG}) \text {; Quat - limit on whole } \\
\text { product (WQB) }\end{array}$ & $\begin{array}{l}\text { Quat - detoxify with } \\
\text { bentonite and can only } \\
\text { discharge for } 24 \mathrm{hr}\end{array}$ & no problem & $\begin{array}{l}\text { contact person } \\
\text { thought Cl limits } \\
\text { might decrease in } \\
\text { the future; also no } \\
\text { state response to } \\
\text { Great Lakes Water } \\
\text { Quality Guidance } \\
\text { yet }\end{array}$ \\
\hline 3 & MD-1 & $\begin{array}{l}\mathrm{Cl}, \mathrm{Br} \text { [in small plant } \\
\text { service water towers } \\
\text { use isothiazoline] }\end{array}$ & $\begin{array}{l}\text { TRO (ELG); isothiazoline - no } \\
\text { limits }\end{array}$ & $\begin{array}{l}\text { discharge main } \\
\text { blowdown to retention } \\
\text { basin; small towers go } \\
\text { to WWTP, then to } \\
\text { retention basin }\end{array}$ & $\begin{array}{l}\text { no problems; letter approvals } \\
\text { for new products }\end{array}$ & \\
\hline 3 & MD-2 & $\mathrm{Cl}, \mathrm{Br}$ & $\begin{array}{l}\text { TRC (ELG) and (WQB during } \\
\text { fish spawning season) }\end{array}$ & $\begin{array}{l}\text { blowdown goes to } \\
\text { sediment ponds }\end{array}$ & $\begin{array}{l}\text { no problem; letter approvals } \\
\text { for new products }\end{array}$ & \\
\hline 3 & PA-1 & $\mathrm{Cl}, \mathrm{Br}$ & TRC (ELG) & $\begin{array}{l}\text { blowdown used for ash } \\
\text { sluicing }\end{array}$ & $\begin{array}{l}\text { application for approval to } \\
\text { discharge chemical additives } \\
\text { made in accordance with PA } \\
\text { DEP "Permitting Guidance on } \\
\text { Use of Chem. Additives," } \\
\text { 1/30/92; letter of approval } \\
\text { required to initiate changes in } \\
\text { dose or to use new chemicals }\end{array}$ & $\begin{array}{l}\text { company is } \\
\text { working through } \\
\text { PA Electric } \\
\text { Association to get } \\
\text { revisions to state } \\
\text { guidance on } \\
\text { chemical additives }\end{array}$ \\
\hline
\end{tabular}


Table 1 - Information on Biocide Usage in Power Plant Cooling Towers

\begin{tabular}{|c|c|c|c|c|c|c|}
\hline Region & Plant & Biocides Used $^{a}$ & Type of Permit Limit ${ }^{b}$ & Operational Practices & Regulatory Experience & Comments \\
\hline 3 & PA-2 & & & & & $\begin{array}{l}\text { This plant was } \\
\text { erroneously } \\
\text { included in the } \\
\text { draft report. It is } \\
\text { left in Table } 1 \text { to } \\
\text { avoid confusion } \\
\text { from renumbering } \\
\text { the remaining PA } \\
\text { plants }\end{array}$ \\
\hline 3 & PA-3 & Cl, Br, Quat (Betz CT-2) & $\begin{array}{l}\text { TRO (ELG); Quat - limit on } \\
\text { whole product (WQB) }\end{array}$ & $\begin{array}{l}\text { molluscicide - detoxify } \\
\text { with bentonite }\end{array}$ & no problems & \\
\hline 3 & PA-4 & Quat & Quat - none detected & $\begin{array}{l}\text { cease blowdown after } \\
\text { Quat dose until none is } \\
\text { detected }\end{array}$ & $\begin{array}{l}\text { letter approval for any } \\
\text { changes; cooperation is fair; } \\
\text { necessary to go through } \\
\text { entire treatment application } \\
\text { process and associated tests } \\
\text { in order to increase dose }\end{array}$ & \\
\hline 3 & PA-5 & $\begin{array}{l}\text { Cl, Br (Betz Slimicide } \\
\text { 694), Quat (Betz } \\
\text { Powerline 625) }\end{array}$ & $\begin{array}{l}\text { FAC (ELG), Quat - none } \\
\text { detected }\end{array}$ & $\begin{array}{l}\text { cease blowdown for up } \\
\text { to } 10 \text { hr after Quat } \\
\text { dose, detoxify with } \\
\text { bentonite }\end{array}$ & $\begin{array}{l}\text { application for approval to } \\
\text { discharge chemical additives } \\
\text { made in accordance with PA } \\
\text { DEP "Permitting Guidance on } \\
\text { Use of Chem. Additives," } \\
\text { 1/30/92; letter of approval } \\
\text { required to initiate changes in } \\
\text { dose or to use new chemicals }\end{array}$ & \\
\hline 3 & PA-6 & $\mathrm{Cl}$ & FAC (ELG) & Chlorinate daily for $2 \mathrm{hr}$ & $\begin{array}{l}\text { application for approval to } \\
\text { discharge chemical additives } \\
\text { made in accordance with PA } \\
\text { DEP "Permitting Guidance on } \\
\text { Use of Chem. Additives," } \\
\text { 1/30/92; letter of approval } \\
\text { required to initiate changes in } \\
\text { dose or to use new chemicals }\end{array}$ & $\begin{array}{l}\text { blowdown is used } \\
\text { for ash sluicing }\end{array}$ \\
\hline 3 & PA-7 & None & None & & & $\begin{array}{l}\text { River water intake } \\
\text { quality results in } \\
\text { very low bio-fouling }\end{array}$ \\
\hline
\end{tabular}


Table 1 - Information on Biocide Usage in Power Plant Cooling Towers

\begin{tabular}{|c|c|c|c|c|c|c|}
\hline Region & Plant & Biocides Used $^{a}$ & Type of Permit Limit ${ }^{b}$ & Operational Practices & Regulatory Experience & Comments \\
\hline 3 & PA-8 & $\mathrm{Cl}$ & FAC (ELG) & $\begin{array}{l}\text { blowdown valve closed } \\
\text { until FAC is not } \\
\text { detected }\end{array}$ & $\begin{array}{l}\text { application for approval to } \\
\text { discharge chemical additives } \\
\text { made in accordance with PA } \\
\text { DEP "Permitting Guidance on } \\
\text { Use of Chem. Additives," } \\
1 / 30 / 92 \text {; letter of approval } \\
\text { required to initiate changes in } \\
\text { dose or to use new chemicals }\end{array}$ & $\begin{array}{l}\text { blowdown } \\
\text { discharges directly } \\
\text { to receiving water. }\end{array}$ \\
\hline & & & & & & \\
\hline 3 & VA-1 & $\mathrm{Cl}, \mathrm{Br}$ & FAC (ELG) & & no problems & \\
\hline 3 & VA-2 & none & & & no problems & \\
\hline 3 & WV-1 & Quat, DGH & $\begin{array}{l}\text { Quat - none detected; DGH - } \\
\text { no acute toxicity; WET testing }\end{array}$ & $\begin{array}{l}\text { Quat \& DGH added at } \\
\text { separate times; Quat is } \\
\text { adsorbed on fly ash }\end{array}$ & $\begin{array}{l}\text { letter approval of any } \\
\text { changes; cooperation good }\end{array}$ & $\begin{array}{l}\text { blowdown is used } \\
\text { to sluice fly ash to } \\
\text { pond }\end{array}$ \\
\hline 3 & WV-2 & Quat, DGH & $\begin{array}{l}\text { Quat - none detected; DGH - } \\
\text { no acute toxicity; WET testing }\end{array}$ & $\begin{array}{l}\text { Quat \& DGH added at } \\
\text { separate times; Quat is } \\
\text { adsorbed on fly ash }\end{array}$ & $\begin{array}{l}\text { letter approval of any } \\
\text { changes; cooperation fair }\end{array}$ & \\
\hline 3 & WV-3 & Quat, DGH & $\begin{array}{l}\text { Quat - none detected; DGH - } \\
\text { no acute toxicity; WET testing }\end{array}$ & $\begin{array}{l}\text { Quat \& DGH added at } \\
\text { separate times; Quat is } \\
\text { adsorbed on fly ash }\end{array}$ & $\begin{array}{l}\text { letter approval of any } \\
\text { changes; cooperation good }\end{array}$ & $\begin{array}{l}\text { blowdown used to } \\
\text { sluice fly ash to } \\
\text { pond }\end{array}$ \\
\hline 3 & WV-4 & $\mathrm{Cl}, \mathrm{Br}$ & FAC - none detected & $\begin{array}{l}\text { blowdown discharged } \\
\text { to combined waste } \\
\text { treatment ponds }\end{array}$ & $\begin{array}{l}\text { minor permit modification } \\
\text { required for change in active } \\
\text { ingredient; letter approval } \\
\text { required for change in } \\
\text { supplier or form of active } \\
\text { ingredient }\end{array}$ & \\
\hline 3 & WV-5 & $\mathrm{Cl}$ & FAC - none detected & $\begin{array}{l}\text { blowdown discharged } \\
\text { to combined waste } \\
\text { treatment system }\end{array}$ & $\begin{array}{l}\text { minor permit modification } \\
\text { required for change in active } \\
\text { ingredient; letter approval } \\
\text { required for change in } \\
\text { supplier or form of active } \\
\text { ingredient }\end{array}$ & \\
\hline
\end{tabular}


Table 1 - Information on Biocide Usage in Power Plant Cooling Towers

\begin{tabular}{|c|c|c|c|c|c|c|}
\hline Region & Plant & Biocides Used ${ }^{a}$ & Type of Permit Limit ${ }^{b}$ & Operational Practices & Regulatory Experience & Comments \\
\hline 3 & WV-6 & $\mathrm{Cl}$ & FAC - none detected & $\begin{array}{l}\text { blowdown discharged } \\
\text { to combined waste } \\
\text { treatment ponds }\end{array}$ & $\begin{array}{l}\text { minor permit modification } \\
\text { required for change in active } \\
\text { ingredient; letter approval } \\
\text { required for change in } \\
\text { supplier or form of active } \\
\text { ingredient }\end{array}$ & \\
\hline & & & & & & \\
\hline 4 & $A L-1$ & $\begin{array}{l}\text { chlorine dioxide; Quat } \\
\text { (Drewsperse L-474 \& } \\
\text { Biosperse 212) }\end{array}$ & FAC (ELG); WET testing & $\begin{array}{l}\text { close blowdown valve } \\
\text { until test shows no } \\
\text { residual TRC, and } \\
\text { Quat shows no } \\
\text { detection, then open. }\end{array}$ & $\begin{array}{l}\text { change in biocide requires } \\
\text { permit modification }\end{array}$ & \\
\hline 4 & $A L-2$ & $\begin{array}{l}\text { Cl, Quat (Betz } \\
\text { Powerline 3625) }\end{array}$ & $\begin{array}{l}\text { FAC (ELG); Quat - none } \\
\text { detected; WET testing }\end{array}$ & $\begin{array}{l}\text { close blowdown valve } \\
\text { until tests show no } \\
\text { residual TRC or Quat; } \\
\text { blowdown goes to } \\
\text { retention pond }\end{array}$ & $\begin{array}{l}\text { change of treatment } \\
\text { chemicals may require permit } \\
\text { modification }\end{array}$ & \\
\hline & & & & & & \\
\hline 4 & FL-1 & $\mathrm{Cl}$ & $\begin{array}{l}\text { TRC (WQB); WET testing; } \\
\text { trihalomethanes }\end{array}$ & dechlorination & $\begin{array}{l}\text { for } \mathrm{Cl} \text {, no problem; previously } \\
\text { denied permission to use } \mathrm{Br} ; \\
\text { approval process for new } \\
\text { biocides is lengthy and } \\
\text { cumbersome }\end{array}$ & $\begin{array}{l}\text { satisfied with } \\
\text { chlorine }\end{array}$ \\
\hline 4 & FL-2 & $\begin{array}{l}\text { Cl, Quat (Betz } \\
\text { Powerline 3625) }\end{array}$ & $\begin{array}{l}\text { FAC (ELG); TRC (WQB); Quat - } \\
\text { none detected; WET testing }\end{array}$ & $\begin{array}{l}\text { no blowdown until TRC } \\
\text { is nondetectable; for } \\
\text { Quat, close blowdown } \\
\text { valve until none is } \\
\text { detected; may detoxify } \\
\text { with bentonite if } \\
\text { necessary }\end{array}$ & $\begin{array}{l}\text { no problems; approval for } \\
\text { Quat needs permit } \\
\text { modification }\end{array}$ & \\
\hline 4 & GA-1 & $\begin{array}{l}\mathrm{Cl}, \mathrm{Br}, \text { triazine-based } \\
\text { algaecide (Calgon } \mathrm{H}- \\
640)\end{array}$ & FAC (ELG); WET & $\begin{array}{l}\text { cease tower blowdown } \\
\text { until tests for FAC } \\
\text { show non-detect, then } \\
\text { begin discharge }\end{array}$ & $\begin{array}{l}\text { change in chemicals may } \\
\text { require permit modification }\end{array}$ & \\
\hline
\end{tabular}


Table 1 - Information on Biocide Usage in Power Plant Cooling Towers

\begin{tabular}{|c|c|c|c|c|c|c|}
\hline Region & Plant & Biocides Used ${ }^{a}$ & Type of Permit Limit ${ }^{b}$ & Operational Practices & Regulatory Experience & Comments \\
\hline 4 & GA-2 & $\mathrm{Cl}-2$ & FAC (ELG) & $\begin{array}{l}\text { cease tower blowdown } \\
\text { until tests for FAC and } \\
\text { Quat show no } \\
\text { detection, then begin } \\
\text { discharge }\end{array}$ & $\begin{array}{l}\text { permit contains list of } \\
\text { approved biocides; changes } \\
\text { require written requests }\end{array}$ & \\
\hline 4 & GA-3 & Cl, Quat (Betz CT-2) & $\begin{array}{l}\text { FAC (ELG); Quat, none } \\
\text { detected (<0.1 ppm) }\end{array}$ & $\begin{array}{l}\text { cease tower blowdown } \\
\text { until tests for FAC and } \\
\text { Quat show no } \\
\text { detection, then begin } \\
\text { discharge }\end{array}$ & $\begin{array}{l}\text { permit contains list of } \\
\text { approved biocides; changes } \\
\text { require written requests }\end{array}$ & \\
\hline 4 & GA-4 & Cl, Quat (Betz CT-2) & $\begin{array}{l}\text { FAC (ELG); Quat, none } \\
\text { detected (<0.1 ppm) }\end{array}$ & $\begin{array}{l}\text { cease tower blowdown } \\
\text { until tests for FAC and } \\
\text { Quat show no } \\
\text { detection, then begin } \\
\text { discharge }\end{array}$ & $\begin{array}{l}\text { permit contains list of } \\
\text { approved biocides; changes } \\
\text { require written requests }\end{array}$ & \\
\hline 4 & GA-5 & $\mathrm{Cl}$ & $\begin{array}{l}\text { TRC none detected }(<0.02 \\
\text { ppm) }\end{array}$ & $\begin{array}{l}\text { cease tower blowdown } \\
\text { until tests for FAC } \\
\text { show no detection, } \\
\text { then begin discharge; } \\
\text { dechlorinate to meet } \\
\text { TRC limit discharge } \\
\text { point }\end{array}$ & $\begin{array}{l}\text { permit contains list of } \\
\text { approved biocides; changes } \\
\text { require written requests }\end{array}$ & \\
\hline & & & & & & \\
\hline 4 & $K Y-1$ & $\mathrm{Cl}, \mathrm{Br}$ & TRO (WQB) & $\begin{array}{l}\text { close blowdown valve } \\
\text { until } \mathrm{Cl} \text { becomes } \\
\text { nondetectable }\end{array}$ & no problem & \\
\hline 4 & $\mathrm{KY}-2$ & Cl, Quat (Betz CT-2) & $\begin{array}{l}\text { TRO (WQB); Quat - no limits, } \\
\text { but company follows none } \\
\text { detected policy }\end{array}$ & $\begin{array}{l}\text { close blowdown valve } \\
\text { until } \mathrm{Cl} \text { becomes } \\
\text { nondetectable; Quat - } \\
\text { detoxify with bentonite }\end{array}$ & no problem & $\begin{array}{l}\text { Quat added to } \\
\text { intake water; only } \\
\text { part of it gets into } \\
\text { tower makeup }\end{array}$ \\
\hline 4 & KY-3 & no blowdown & & & & \\
\hline 4 & $\mathrm{KY}-4$ & Cl, Br, Quat (Betz CT-2) & $\begin{array}{l}\text { TRO (ELG); Quat - no limits, } \\
\text { but company follows none } \\
\text { detected policy }\end{array}$ & $\begin{array}{l}\text { Quat - detoxify with } \\
\text { bentonite }\end{array}$ & not much problem & \\
\hline 4 & KY-5 & Cl, Br, Quat (Betz CT-2) & $\begin{array}{l}\text { FAO (ELG); TRO (WQB); Quat } \\
\text { none detected }\end{array}$ & $\begin{array}{l}\text { Quat - detoxify with } \\
\text { bentonite }\end{array}$ & & \\
\hline
\end{tabular}


Table 1 - Information on Biocide Usage in Power Plant Cooling Towers

\begin{tabular}{|c|c|c|c|c|c|c|}
\hline Region & Plant & Biocides Used $^{a}$ & Type of Permit Limit ${ }^{b}$ & Operational Practices & Regulatory Experience & Comments \\
\hline 4 & KY-6 & $\begin{array}{l}\text { none on main cooling } \\
\text { water system; use Quat } \\
\text { (Betz CT-2) on service } \\
\text { water }\end{array}$ & none & $\begin{array}{l}\text { Quat - detoxify with } \\
\text { bentonite }\end{array}$ & $\begin{array}{l}\text { need to get permission for } \\
\text { each annual application of } \\
\text { Quat }\end{array}$ & \\
\hline & & & & & & \\
\hline 4 & $\mathrm{NC}-1$ & $\mathrm{Cl}$ & TRC (ELG) & dechlorination & no problem & \\
\hline 4 & $\mathrm{NC}-2$ & $\begin{array}{l}\text { 1-bromo, 3-chloro, 5,5- } \\
\text { dimethyl hydantoin } \\
\text { (Betz Bio-Trol 88P) }\end{array}$ & FAC (ELG) & $\begin{array}{l}\text { long detention time in } \\
\text { ash pond }\end{array}$ & no problem & \\
\hline 4 & $\mathrm{NC}-3$ & none & no chlorine added to discharge & & no problem & \\
\hline 4 & $\mathrm{NC}-4$ & $\begin{array}{l}\text { Quat (Betz Powerline } \\
3625)\end{array}$ & TRC (ELG); FAC (ELG) & $\begin{array}{l}\text { long detention time in } \\
\text { ash pond; blowdown } \\
\text { discharge discontinued } \\
\text { during and immediately } \\
\text { after biocide } \\
\text { application }\end{array}$ & no problem & \\
\hline & & & & & & \\
\hline 4 & $\mathrm{TN}-1$ & $\begin{array}{l}\text { none; use mechanical } \\
\text { cleaning }\end{array}$ & & & & \\
\hline 4 & TN-2 & $\begin{array}{l}\text { 1-bromo, 3-chloro, 5,5- } \\
\text { dimethyl hydantoin }\end{array}$ & TRO (WQB) & $\begin{array}{l}\text { blowdown discharged } \\
\text { to holding pond }\end{array}$ & no problem & \\
\hline 5 & IL-1 & $\begin{array}{l}\mathrm{Cl} \text {, permitted to use } \mathrm{Br} \\
\text { but have not yet used it }\end{array}$ & $\begin{array}{l}\text { TRC (ELG); TRO (WQB) if } \mathrm{Br} \text { is } \\
\text { ever used }\end{array}$ & $\begin{array}{l}\text { blowdown discontinued } \\
\text { during } \mathrm{Cl} \text { addition; } \\
\text { blowdown mixed with } \\
\text { nonchlorinated water } \\
\text { before discharge }\end{array}$ & & \\
\hline
\end{tabular}


Table 1 - Information on Biocide Usage in Power Plant Cooling Towers

\begin{tabular}{|c|c|c|c|c|c|c|}
\hline Region & Plant & Biocides Used ${ }^{a}$ & Type of Permit Limit ${ }^{b}$ & Operational Practices & Regulatory Experience & Comments \\
\hline 5 & IN-1 & $\begin{array}{l}\text { Quat slimicide (Betz } \\
\text { Powerline 3625), quat } \\
\text { molluscide (Betz CT-2) }\end{array}$ & $\begin{array}{l}\text { Quats - below limit of } \\
\text { detection; in addition, } \\
\text { molluscide limited to 12-hr } \\
\text { duration }\end{array}$ & $\begin{array}{l}\text { molluscicide - cease } \\
\text { blowdown during } \\
\text { treatment; slimicide, } \\
\text { cease blowdown for } 24 \\
\text { hr following start of } \\
\text { treatment; blowdown } \\
\text { goes to treatment } \\
\text { ponds before } \\
\text { discharge }\end{array}$ & $\begin{array}{l}\text { permit modification required } \\
\text { for changes in biocide; state } \\
\text { action on permit requests was } \\
\text { slow initially but has been } \\
\text { good recently }\end{array}$ & \\
\hline 5 & IN-2 & $\mathrm{Cl}$ & FAC (ELG) & none & $\begin{array}{l}\text { permit modification required } \\
\text { to change biocides }\end{array}$ & \\
\hline 5 & MI-1 & Cl, Quat (Betz CT-4) & $\begin{array}{l}\mathrm{Cl}(\mathrm{WQB}), \text { TRO (WQB), Quat - } \\
\text { none detected }\end{array}$ & $\begin{array}{l}\text { Cl - dechlorination; } \\
\text { Quat - detoxify with } \\
\text { bentonite, delay } \\
\text { discharge, WET tests }\end{array}$ & $\begin{array}{l}\text { permission for using new } \\
\text { biocides is time-consuming } \\
\text { but is not a problem; approval } \\
\text { may be done by letter or } \\
\text { permit modification }\end{array}$ & \begin{tabular}{l|} 
Quat is only used \\
on service water \\
and fire protection \\
water; never had a \\
request denied, but \\
may decide to \\
withdraw request if \\
requirements are \\
too strict
\end{tabular} \\
\hline 5 & $\mathrm{MI}-2$ & Cl, Quat (Betz CT-4) & $\begin{array}{l}\mathrm{Cl}(\mathrm{WQB}), \text { TRO (WQB), Quat - } \\
\text { none detected }\end{array}$ & $\begin{array}{l}\text { Quat - detoxify with } \\
\text { bentonite }\end{array}$ & $\begin{array}{l}\text { permission for using new } \\
\text { biocides is time-consuming } \\
\text { but is not a problem; approval } \\
\text { may be done by letter or } \\
\text { permit modification }\end{array}$ & \\
\hline 5 & $\mathrm{MN}-1$ & $\begin{array}{l}\mathrm{Cl}, \mathrm{Br}, \text { Quat (Nalco } \\
\text { Macrotrol or Betz CT-4) }\end{array}$ & $\begin{array}{l}\text { TRO (WQB); maximum feed } \\
\text { rate for Quat }\end{array}$ & $\begin{array}{l}\text { control the addition of } \\
\text { biocides to maintain } \\
\text { limits; blowdown is } \\
\text { directed to a discharge } \\
\text { canal; detoxification of } \\
\text { quats may be required }\end{array}$ & $\begin{array}{l}\text { approval to switch to new } \\
\text { products has required } \\
\text { complicated demonstrations }\end{array}$ & $\begin{array}{l}\text { Quat is used only } \\
\text { on emergency } \\
\text { intake line; } \mathrm{Cl} \text {, and } \\
\mathrm{Br} \text { are used only on } \\
\text { service water } \\
\text { system }\end{array}$ \\
\hline
\end{tabular}


Table 1 - Information on Biocide Usage in Power Plant Cooling Towers

\begin{tabular}{|c|c|c|c|c|c|c|}
\hline Region & Plant & Biocides Used $^{a}$ & Type of Permit Limit ${ }^{b}$ & Operational Practices & Regulatory Experience & Comments \\
\hline 5 & $\mathrm{MN}-2$ & $\begin{array}{l}\text { Cl, Br, Quat (Nalco } \\
\text { Macrotrol, Buckman } \\
\text { Bulab 6002, or Betz CT- } \\
\text { 4) }\end{array}$ & $\begin{array}{l}\text { TRO (WQB); maximum feed } \\
\text { rate for Quat }\end{array}$ & $\begin{array}{l}\text { control the addition of } \\
\text { biocides to maintain } \\
\text { limits; blowdown is } \\
\text { directed to a discharge } \\
\text { canal; detoxification of } \\
\text { quats may be required }\end{array}$ & $\begin{array}{l}\text { approval to switch to new } \\
\text { products has required } \\
\text { complicated demonstrations }\end{array}$ & $\begin{array}{l}\text { Quats are } \\
\text { approved only for } \\
\text { service water } \\
\text { system and fire } \\
\text { protection system, } \\
\text { except for CT-4, } \\
\text { which is approved } \\
\text { for backup } \\
\text { treatment in the } \\
\text { main circulation } \\
\text { system if thermal } \\
\text { treatment is } \\
\text { insufficient }\end{array}$ \\
\hline 5 & MN-3 & $\mathrm{Cl}, \mathrm{Br}$ & TRO (WQB) & $\begin{array}{l}\text { blowdown is held for } \\
\text { at least } 24 \text { hours } \\
\text { before discharge }\end{array}$ & $\begin{array}{l}\text { approval to switch to new } \\
\text { products has required } \\
\text { complicated demonstrations }\end{array}$ & \\
\hline 5 & $\mathrm{OH}-1$ & $\begin{array}{l}\mathrm{Cl}, 1 \text {-bromo, 3-chloro, } \\
\text { 5,5-dimethyl hydantoin }\end{array}$ & TRO (ELG) & & no problems & $\begin{array}{l}\text { do not request } \\
\text { permission to use a } \\
\text { biocide unless they } \\
\text { think it can be } \\
\text { easily approved }\end{array}$ \\
\hline 5 & $\mathrm{OH}-2$ & Cl, Br, Quat (Betz CT-2) & Quat - none detected & $\begin{array}{l}\text { Quat - detoxify with } \\
\text { bentonite }\end{array}$ & & \\
\hline 5 & $\mathrm{OH}-3$ & $\mathrm{Cl}$ & TRC (ELG) & dechlorination & good cooperation with state & none \\
\hline 5 & $\mathrm{OH}-4$ & $\mathrm{Cl}$ & FAC (ELG) & $\begin{array}{l}\text { blowdown goes to } \\
\text { combined waste } \\
\text { treatment ponds }\end{array}$ & $\begin{array}{l}\text { Letter approval required to } \\
\text { change treatment or feed rate }\end{array}$ & \\
\hline 5 & $\mathrm{OH}-5$ & $\begin{array}{l}\text { Quat (Betz Powerline } \\
3625)\end{array}$ & Quat - none detected & $\begin{array}{l}\text { blowdown goes to } \\
\text { combined waste } \\
\text { treatment ponds }\end{array}$ & $\begin{array}{l}\text { Letter approval required to } \\
\text { change treatment or feed rate }\end{array}$ & \\
\hline 5 & $\mathrm{OH}-6$ & $\begin{array}{l}\text { Cl, Quat (Betz } \\
\text { Powerline 3625) }\end{array}$ & FAC (ELG) & $\begin{array}{l}\text { blowdown goes to } \\
\text { combined waste } \\
\text { treatment ponds }\end{array}$ & $\begin{array}{l}\text { Letter approvals required for } \\
\text { change in biocides }\end{array}$ & \\
\hline
\end{tabular}


Table 1 - Information on Biocide Usage in Power Plant Cooling Towers

\begin{tabular}{|c|c|c|c|c|c|c|}
\hline Region & Plant & Biocides Used ${ }^{a}$ & Type of Permit Limit ${ }^{b}$ & Operational Practices & Regulatory Experience & Comments \\
\hline 5 & WI-1 & $\begin{array}{l}\mathrm{Cl}, \mathrm{Br} \text {; several } \\
\text { molluscicides tried, only } \\
\text { Quat (CT-2) is currently } \\
\text { in use about once/year; } \\
\text { plant also uses thermal } \\
\text { treatments in parts of } \\
\text { cooling system; draw } \\
\text { down of intake water } \\
\text { settling basins done } \\
\text { once/year in winter to } \\
\text { freeze zebra mussels }\end{array}$ & TRO (WQB); Quat (WQB) & $\begin{array}{l}\text { close blowdown valve } \\
\text { during and immediately } \\
\text { after chlorination/ } \\
\text { bromination or Quat } \\
\text { addition until limits can } \\
\text { be met }\end{array}$ & $\begin{array}{l}\text { no problems; letter approval } \\
\text { for new products }\end{array}$ & $\begin{array}{l}\text { company contact } \\
\text { does not expect } \\
\text { GLI to have much } \\
\text { effect on biocide } \\
\text { usage }\end{array}$ \\
\hline & & & & & & \\
\hline 6 & NM-1 & $\begin{array}{l}\text { Cl, Quat (Buckman } \\
412 \text { ) }\end{array}$ & FAC (ELG) & $\begin{array}{l}\text { close off blowdown } \\
\text { when chlorinating }\end{array}$ & no problems & \\
\hline 6 & NM-2 & none & & & & zero discharge \\
\hline & & & & & & \\
\hline 6 & OK-1 & $\begin{array}{l}\mathrm{Cl} \text {; recent trial of } \mathrm{Cl} \text { and } \\
\mathrm{Br}\end{array}$ & FAC (ELG) & $\begin{array}{l}\text { close blowdown valve } \\
\text { during } \mathrm{Cl} \text { addition and } \\
\text { for } 10 \text { minutes } \\
\text { thereafter; discharge to } \\
\text { retention pond }\end{array}$ & no problems & $\begin{array}{l}\text { soon expect to } \\
\text { receive a new } \\
\text { permit with stricter } \\
\text { Cl limits }\end{array}$ \\
\hline 6 & $\mathrm{OK}-2$ & $\mathrm{Cl}$ & FAC (ELG) & $\begin{array}{l}\text { cease tower blowdown } \\
\text { until test shows no } \\
\text { residual, then begin } \\
\text { blowdown }\end{array}$ & $\begin{array}{l}\text { permit renewal may require } \\
\text { discharge }<0.1 \text { TRC; different } \\
\text { versions of same product } \\
\text { handled by letter; different } \\
\text { products may require permit } \\
\text { modification }\end{array}$ & $\begin{array}{l}\text { tower blowdown is } \\
\text { combined with } \\
\text { other plant waste } \\
\text { streams and } \\
\text { discharged to } \\
\text { receiving water } \\
\text { without further } \\
\text { treatment }\end{array}$ \\
\hline 6 & $\mathrm{OK}-3$ & $\mathrm{Cl}$ & FAC (ELG); WET testing & $\begin{array}{l}\text { cease tower blowdown } \\
\text { until test shows no } \\
\text { residual, then begin } \\
\text { blowdown }\end{array}$ & $\begin{array}{l}\text { permit renewal requires } \\
\text { discharge }<0.1 \mathrm{ppm} \text { TRC; any } \\
\text { change in type of product may } \\
\text { require permit modification }\end{array}$ & \\
\hline
\end{tabular}


Table 1 - Information on Biocide Usage in Power Plant Cooling Towers

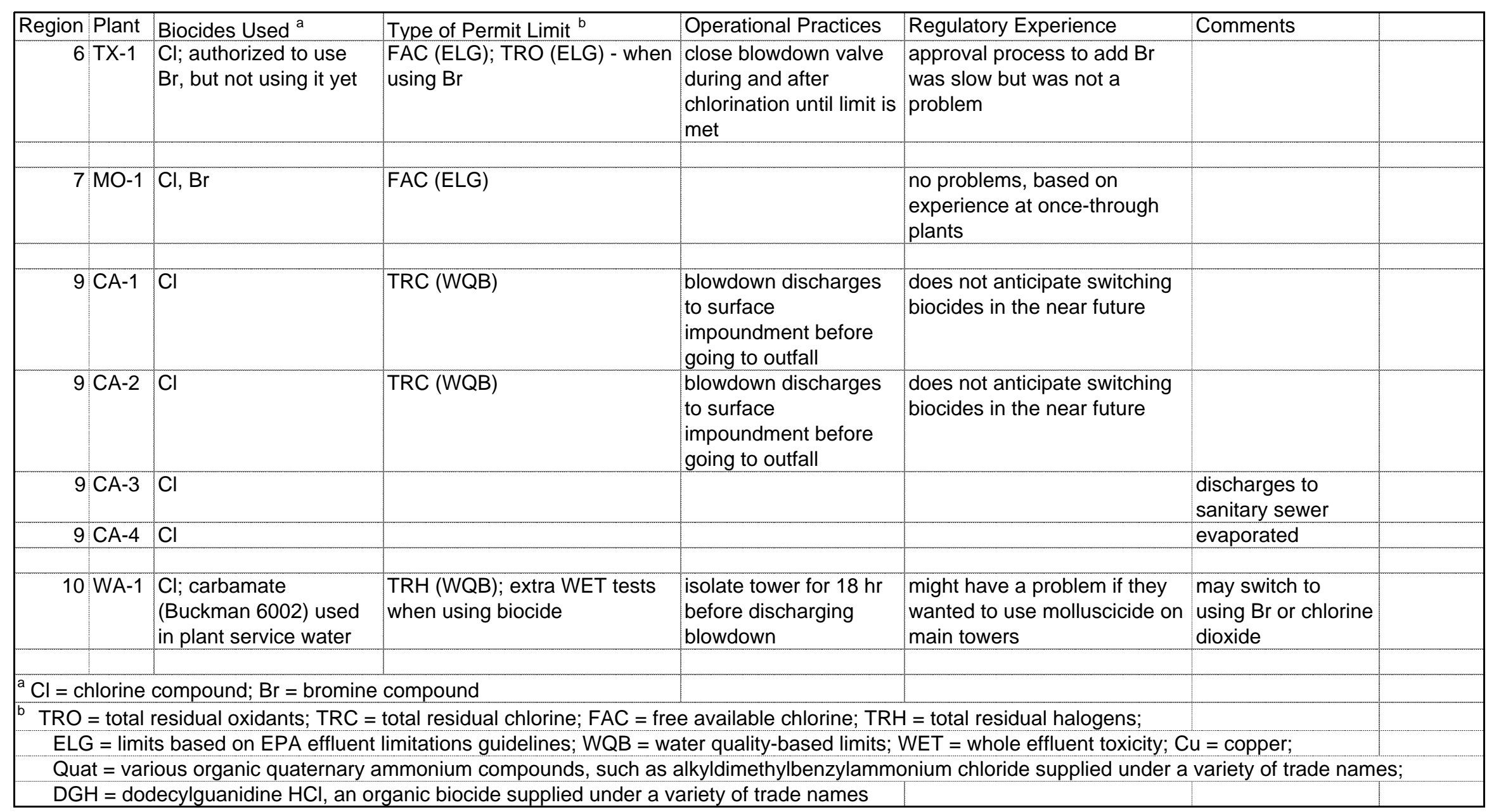


Table 2 - Distribution of Power Plants Providing Data on Biocide Usage

\begin{tabular}{|c|c|c|c|c|}
\hline EPA Region & No. of Plants & \% of Total & Capacity (MW) & $\%$ of Total \\
\hline 1 & 0 & 0 & 0 & 0 \\
\hline 2 & 2 & 3 & 2,384 & 2 \\
\hline 3 & 17 & 25 & 26,283 & 26 \\
\hline 4 & 21 & 31 & 31,841 & 31 \\
\hline 5 & 15 & 22 & 31,981 & 31 \\
\hline 6 & 6 & 9 & 5,629 & 6 \\
\hline 7 & 1 & 1 & 1,236 & 1 \\
\hline 8 & 0 & 0 & 0 & 0 \\
\hline 9 & 4 & 6 & 1,356 & 1 \\
\hline 10 & 1 & 1 & 1,201 & 1 \\
\hline Total & 67 & 100 & 101,911 & 100 \\
\hline
\end{tabular}


Table 3 - Distribution of U.S. Power Plants Using Cooling Towers for Main Condensor Cooling

\begin{tabular}{|c|c|c|c|c|}
\hline EPA Region & No. of Units & \%of Total & Capacity (MW) & \% of Total \\
\hline 1 & 6 & 0 & 540 & 0 \\
\hline 2 & 8 & 1 & 2,628 & 1 \\
\hline 3 & 79 & 13 & 47,149 & 23 \\
\hline 4 & 72 & 12 & 38,085 & 19 \\
\hline 5 & 78 & 13 & 32,290 & 16 \\
\hline 6 & 135 & 22 & 32,280 & 16 \\
\hline 7 & 66 & 11 & 9,922 & 5 \\
\hline 8 & 71 & 12 & 19,345 & 9 \\
\hline 9 & 89 & 15 & 18,909 & 9 \\
\hline 10 & 6 & 1 & 2,632 & 1 \\
\hline Total & 610 & 100 & 203,780 & 100 \\
\hline
\end{tabular}


Table 4 - Frequency of Usage of Different Types of Biocides at Power Plants

\begin{tabular}{|l|c|}
\hline Type of Biocide & $\begin{array}{c}\text { No. of Plants Using That Biocide } \\
\text { Alone or in Combination }\end{array}$ \\
\hline chlorine & 53 \\
\hline quats & 27 \\
\hline bromine & 18 \\
\hline dodecylguanidine hydrochloride (DGH) & 3 \\
\hline 1-bromo, 3-chloro, 5,5-dimethyl hydantoin (BCDMH) & 3 \\
\hline chlorine dioxide & 1 \\
\hline triazine & 1 \\
\hline none used & 7 \\
\hline & \\
\hline Total plants surveyed $=67$ & \\
\hline
\end{tabular}


Table 5 - Frequency of Usage of Biocide Combinations At Power Plants

\begin{tabular}{|l|c|}
\hline Biocide Combination & No. of Plants Using That Combination \\
\hline chlorine alone & 22 \\
\hline chlorine and bromine & 11 \\
\hline chlorine and quats & 10 \\
\hline chlorine, bromine, and quats & 10 \\
\hline quats alone & 3 \\
\hline none used & 7 \\
\hline all others & 4 \\
\hline & \\
\hline Total & 67 \\
\hline
\end{tabular}


Table 6 - Information on Biocide Usage in Refinery Cooling Towers

\begin{tabular}{|c|c|c|c|c|c|c|}
\hline Region & Plant & Biocides Used $^{a}$ & Type of Permit Limit ${ }^{b}$ & Operational Practices & $\begin{array}{l}\text { Regulatory } \\
\text { Experience }\end{array}$ & Comments \\
\hline 3 & VA-1R & $\mathrm{Cl}, \mathrm{Br}$ & none & & no problem & $\begin{array}{l}\text { no need to notify agency to } \\
\text { change products }\end{array}$ \\
\hline 4 & $K Y-1 R$ & $\begin{array}{l}\text { isothiazoline (Drew } \\
\text { Biosperse 250), } \\
\text { gluteraldehyde (Drew } \\
\text { Biosperse 254); } \\
\text { Performax } 405\end{array}$ & & $\begin{array}{l}\text { alternate three } \\
\text { products to keep bugs } \\
\text { from acclimating }\end{array}$ & $\begin{array}{l}\text { no problem; fairly } \\
\text { quick approval from } \\
\text { state }\end{array}$ & \\
\hline 5 & IN-1R & $\mathrm{Cl}, \mathrm{Br}$ & TRC - none detected & & no problem & $\begin{array}{l}\text { need approval letter to use new } \\
\text { products }\end{array}$ \\
\hline 5 & $M N-1 R$ & $\begin{array}{l}\text { isothiazoline (Drew } \\
\text { Biosperse 250), } \\
\text { gluteraldehyde (Drew } \\
\text { Biosperse 254); } \\
\text { Performax 405 }\end{array}$ & & $\begin{array}{l}\text { alternate three } \\
\text { products to keep bugs } \\
\text { from acclimating }\end{array}$ & $\begin{array}{l}\text { no problem; fairly } \\
\text { quick approval from } \\
\text { state }\end{array}$ & \\
\hline 5 & $\mathrm{OH}-1 \mathrm{R}$ & $\begin{array}{l}\text { isothiazoline (Drew } \\
\text { Biosperse 250), } \\
\text { gluteraldehyde (Drew } \\
\text { Biosperse 254); } \\
\text { Performax 405 }\end{array}$ & & $\begin{array}{l}\text { alternate three } \\
\text { products to keep bugs } \\
\text { from acclimating }\end{array}$ & $\begin{array}{l}\text { no problem; fairly } \\
\text { quick approval from } \\
\text { state }\end{array}$ & \\
\hline 6 & AR-1R & $\mathrm{Cl}, \mathrm{Br}$ & WET testing & & & $\begin{array}{l}\text { no approval needed to change } \\
\text { products }\end{array}$ \\
\hline 6 & LA-1R & $\mathrm{Br}$ & none & & no problems & $\begin{array}{l}\text { State must be notified of } \\
\text { product change }\end{array}$ \\
\hline 6 & LA-2R & $\begin{array}{l}\text { bromochloromethylethyl } \\
\text { hydantoin, } \\
\text { gluteraldehyde, Cl }\end{array}$ & none & & no problems & $\begin{array}{l}\text { State must be notified of } \\
\text { product change }\end{array}$ \\
\hline 6 & TX-1R & $\mathrm{Cl}, \mathrm{Br}$, chlorine dioxide & & & no problems & $\begin{array}{l}\text { no approval needed to change } \\
\text { products }\end{array}$ \\
\hline
\end{tabular}


Table 6 - Information on Biocide Usage in Refinery Cooling Towers

\begin{tabular}{|c|c|c|c|c|c|c|}
\hline Region & \begin{tabular}{l|l} 
Plant \\
\end{tabular} & Biocides Used $^{a}$ & Type of Permit Limit ${ }^{b}$ & Operational Practices & $\begin{array}{l}\text { Regulatory } \\
\text { Experience }\end{array}$ & Comments \\
\hline 9 & CA-1R & $\mathrm{Cl}, \mathrm{Br}$ & & & no problems & $\begin{array}{l}\text { State needs to be notified } \\
\text { before changing products }\end{array}$ \\
\hline 10 & WA-1R & $\begin{array}{l}\mathrm{Cl} \text {, isothiazoline } \\
\text { (Chemtreat CL-2150, } \\
\text { Betz C-68) }\end{array}$ & WET testing & $\begin{array}{l}\text { blowdown valve is } \\
\text { closed until biocide } \\
\text { concentration is low }\end{array}$ & no problems & $\begin{array}{l}\text { no approval needed to change } \\
\text { products but must test for } \\
\text { biocides and pesticides used } \\
\text { and report to state four times } \\
\text { during next permit period }\end{array}$ \\
\hline 10 & WA-2R & $\begin{array}{l}\text { dodecylguanidine } \\
\text { hydrochloride and } \\
\text { methylene bis- } \\
\text { thiocyanate (Betz C-31) }\end{array}$ & WET testing & & no problems & $\begin{array}{l}\text { no approval needed to change } \\
\text { products }\end{array}$ \\
\hline 10 & WA-3R & $\mathrm{Cl}$ & & & no problems & \\
\hline 10 & WA-4R & $\begin{array}{l}\text { isothiazoline (Drew } \\
\text { Biosperse 250), Cl }\end{array}$ & WET testing & & no problems & $\begin{array}{l}\text { no approval needed to change } \\
\text { products }\end{array}$ \\
\hline 10 & WA-5R & $\mathrm{Cl}, \mathrm{Br}$ & TRC & & no problems & $\begin{array}{l}\text { need to notify state before } \\
\text { using new products }\end{array}$ \\
\hline
\end{tabular}


Table 7 - Frequency of Usage of Different Types of Biocides at Refineries

\begin{tabular}{|l|c|}
\hline Type of Biocide & $\begin{array}{c}\text { No. of Plants Using That Biocide } \\
\text { Alone or in Combination }\end{array}$ \\
\hline chlorine & 10 \\
\hline bromine & 7 \\
\hline isothiazoline & 5 \\
\hline gluteraldehyde & 3 \\
\hline quats & 1 \\
\hline chlorine dioxide & 1 \\
\hline 1-bromo, 3-chloro, 5,5-dimethyl hydantoin (BCDMH) & 1 \\
\hline dodecylguanidine hydrochloride (DGH) & 1 \\
\hline methylene bis-thiocyanate (MBT) & \\
\hline & \\
\hline Total plants surveyed = 15 & \\
\hline
\end{tabular}




\section{Appendix A - Detailed Excerpts and Summaries of State Regulations Applicable to Discharges Containing Biocides}

\section{Table of Contents}

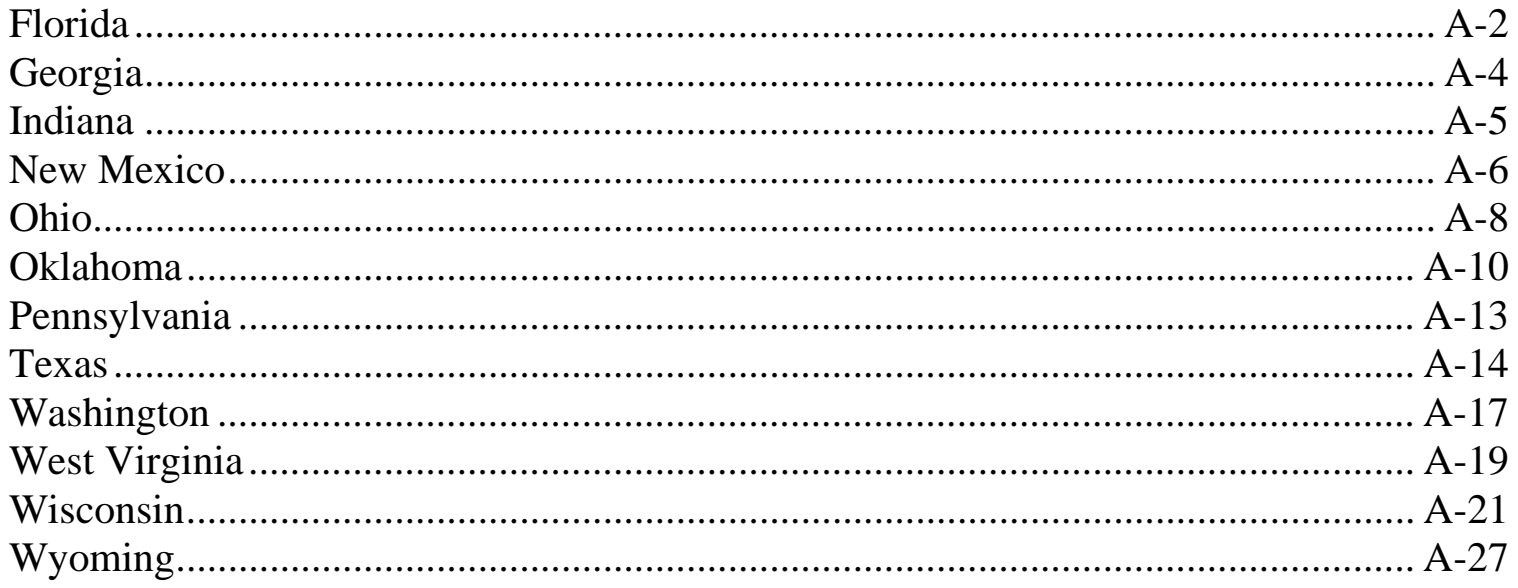

Appendix A provides information on the usage and discharge of biocides from the regulations of 12 states. These states were selected to represent different regions of the country where cooling towers are used. Excerpts from the regulations are provided, and summaries of other relevant information derived from conversations with state regulators are provided in brackets [ ]. These summaries were obtained during conversations between Mary Raivel, Argonne National Laboratory, Washington, D.C., and a staff member of a state agency responsible for surface water discharge permitting. The summaries are provided for information that is not contained in the state regulations. The information in Appendix A is presented as supplemental information and is not intended to be a complete listing of all state rules and regulations influencing the use and discharge of biocides.

Much of the text in Appendix A consists of excerpts from the regulations of numerous states. In some cases, the wording may be unwieldy or confusing. We have not attempted to revise the states' phrasing, punctuation, grammar, or choice of terms. The information, as presented, is useful, nonetheless.

Florida (Florida Administrative Code Annotated)

\section{Biocide-specific regulations:}

\section{Chapter 62-302 - Surface Water Quality Standards} 62-302.530 Table: Surface Water Quality Criteria

The criteria are: Bromine (free molecular): less than or equal to $0.1 \mathrm{mg} / \mathrm{l}$ for Class II (Shellfish propagation or harvesting) waters and Class III Marine (Healthy well-balanced population of fish and wildlife) waters; Chlorine (total residual): less than or equal to $0.01 \mathrm{mg} / \mathrm{l}$ for Class I (Potable water) and Class III Fresh, as well as for Class II and Class III Marine waters. 
Chapter 62-620 - Wastewater Facility Permitting

62-620.425 Application Requirements for Discharges of Non-process Wastewater

[Applies where effluent guidelines or new source performance standards have not been promulgated. Includes revisions to a permit to substantially modify an already permitted industrial wastewater facility or activity, or renewal of an existing permit].

(2) (d) Requires applicant to identify cooling water additives, if any, that are used or expected to be used upon commencement of operations

(e) Applicants for permits for new or substantially modified facilities or activities shall submit estimates of the TRC, if chlorine is used, that will be found in their effluent. The level should be estimated as concentration and as total mass. All other applicants shall submit, at a minimum, quantitative data on the effluent discharge.

Cooling water-specific regulations:

62-660.400 Effluent limitations.

(1) (q) Discharges from steam electric generating plants existing or licensed by July 1,1984 shall not be required to be treated to a greater extent than may be necessary to assure:

1. That the quality of nonthermal components of discharges from nonrecirculated cooling water systems is as high as the quality of the make-up waters; or

2. That the quality of nonthermal components of discharges from recirculated cooling water systems is no lower than is allowed for blowdown from such systems; or

3. That the quality of noncooling system discharges, which receive make-up water from a receiving body of water that does not meet applicable Department water quality standards, is as high as the quality of the receiving body of water.

Water quality-based effluent limitations regulations:

(2) Effluent Limitations Based on Water Quality Considerations.

(d) The effluent limitations based on water quality standards shall be determined in accordance with Chapter 62-650 of the Florida Administrative Code by application of accepted scientific methods based upon consideration of the following:

1. The condition of the receiving body of water including present and future flow conditions and present and future sources of pollutants.

2. The nature, volume and frequency of the proposed discharge of waste including any possible synergistic effects with other pollutants which may be present in the receiving body of water. 
Permit application regulations:

62-620.300(3)(a)3.

For modifications of a facility [or activity] which relate solely to the discharge of wastes into surface water which will only affect the treatment works or the quantity, nature or quality of the discharge when placed in operation, a wastewater permit revision shall be obtained before placing the modifications in operation.

62-620.300(3)(b).

Power plants described under 40 CFR 423, insofar as they are not certified under the Florida Electrical Power Plant Siting Act, may initiate construction of modifications that relate to the discharge of wastes to both ground and surface water without a permit revision if the modifications do not affect the treatment works or the quantity, nature, or quality of the discharge until the modifications are placed in operation. A wastewater permit revision shall be obtained before placing these modifications into operation. 
Georgia (Official Compilation Rules and Regulations of the State of Georgia)

Permit application regulations:

[There are no effluent guidelines for biocides that impose restrictions in NPDES permits beyond the basic narrative water quality standards. If a discharger wanted to begin using a new biocide, in most cases, only a modification of the existing permit would be required. The discharger would have to demonstrate compliance with water quality standards; bioassays might have to be used, or the state might ask the permittee to demonstrate that after suitable mixing (through use of a mixing zone or otherwise), the discharge would not be toxic.]

\section{Mixing zones:}

\section{Chapter 391-3-6 Water Quality Control}

Section 391-3-6.03 Water Use Classifications and Water Quality Standards.

(10) Use of a reasonable and limited mixing zone may be permitted on receipt of satisfactory evidence that such a zone is necessary and that it will not create an objectionable or damaging pollution condition. Protection from acute toxicity shall be provided within any Environmental Protection Division-designated mixing zone to ensure a zone of safe passage for aquatic organisms. The procedure is as described in paragraph 391-3-6-.06(4)(d)(5)(vi), except that the numerical pass/fail criteria applies to the end-of-pipe without the benefit of dilution provided by the receiving stream. 
Indiana (Indiana Administrative Code)

Cooling water-specific regulations:

[From Attachment A, requirements pursuant to 327 IAC]

For determining safe concentrations of recirculating water system and noncontact cooling water additives, the following information should be submitted or addressed:

1. Toxicity (LC50 or the median lethal concentration) of the additive as determined by 96hour flow through bioassays for fish (preferably fathead minnow or bluegill for warm water species or rainbow trout for cold water species) and 48-hour static renewal for invertebrates. Testing procedures to determine LC50 values should follow EPA Guidelines. Static bioassays are acceptable only if the treatment chemical is persistent.

2. The test species selected should be characteristic of the more sensitive representative aquatic species in the receiving stream.

3. The test temperature should be maintained at 20 degrees Celsius for cold water species and at 30 degrees Celsius for warm water species (higher test temperatures are chosen in order to simulate worst case conditions.

4. The relationship of toxicity to $\mathrm{pH}$.

5. The relationship of toxicity to water hardness.

6. Product persistence in the environment and N Octanol - Water Partition Coefficient and Bioconcentration Factor (BCF) if available.

Permit application regulations:

[See Attachment A and 327 IAC 2-1-8.2(3) and 327 IAC 2-1-8.3(4) for requirements specifically applicable to biocides]

Dischargers of blowdown from recirculating water or non-contact cooling water systems are required to disclose information on the water treatment additives in use and to demonstrate that such additives will not violate Indiana Water Quality Standards for aquatic life. To meet the requirements, dischargers must submit the required information to the Indiana Department of Environmental Management, Office of Water Management, Permits Section when applying for a new or renewal NPDES permit or modification thereof. This information is used to establish permit limitations to comply with all Indiana Water Quality Standards. If a permittee changes water treatment additives during the term of their NPDES permit, this information must be submitted to the Permits Section, and approval of the change must be received prior to the use of the new product(s).

Indiana also requires the discharger to submit or otherwise address additional information for determining safe concentrations of recirculating water system and noncontact cooling water additives. 
New Mexico (Water Quality Control Regulations)

Biocide-specific regulations:

Chapter 6 - Water Quality; Part 1, Subpart III

Section 3101 - Standards applicable to attainable or designated uses unless otherwise specified in Subpart II.

J. The following schedule of numeric standards and equations for the substances listed shall apply to the subcategories of fisheries identified in Section 3101 of these standards:

1. Acute Standards ...

Total chlorine residual $19 \mu \mathrm{g} / \mathrm{l}$

2. Chronic Standards ...

Total chlorine residual $11 \mu \mathrm{g} / \mathrm{l}$

L. Wildlife Habitat: The following narrative standard shall apply:

3. Discharges to waters which are designated for wildlife habitat uses, but not for fisheries uses, shall not contain levels of ammonia or chlorine in amounts which reduce biological productivity and/or species diversity to levels below those which occur naturally, and in no case shall contain chlorine in excess of $1 \mathrm{mg} / \mathrm{l} \ldots$

Water quality standards regulations (general):

\section{Section 1102 General Standards}

F. Toxic Substances: Chronic standard for the use to be protected is in section 3101; for toxic substances not listed in section 3101, the following provisions shall be applied in numeric order in accordance with sections 1103, 1105, and 1106.

\section{CWA; OR}

1. Chronic standard: "criterion continuous concentration" pursuant to section 304(a) of the

2. Using results of toxicological studies published in scientific journals, a geometric mean LC50 value shall be calculated for the particular species, genus or group which is representative of the form of life to be preserved. The chronic standard for a toxic substance which does not bioaccumulate shall be $10 \%$ of the calculated geometric mean LC50 value; OR

3. Chronic standard for a toxic substance which does bioaccumulate shall be the standard calculated under paragraph (2) above adjusted by a bioaccumulation factor for the particular species, genus or group representative of the particular form of life to be preserved. When such definitive information has not been published, the chronic standard for a bioaccumulating toxic substance shall be $1 \%$ of the calculated geometric mean LC50 value.

Mixing zone regulations: 


\section{Applicability of Water Quality Standards}

D. Mixing Zones: Effluent limitations shall be developed which will protect the most sensitive existing, designated or attainable use of the receiving water.

E. Limitations: Wastewater mixing zones, in which the numeric standards set under Section 1102.F., Subpart H (Sections 2100-2805) or Section 3101 may be exceeded, shall be subject to the following limitations:

1. Mixing zones are not allowed for discharges to publicly owned lakes or reservoirs ...

2. The acute numeric standards, as set out in Section 3101.J.1 of these standards, shall be attained at the point of discharge for any discharge to a water of the State with a designated fishery use.

4. The areal extent and concentration isopleths of a particular mixing zone will depend on site-specific conditions such as, but not limited to, wastewater flow, receiving water critical low flow, outfall design, channel characteristics and climate conditions and, if needed, shall be determined on a case-by-case basis. ... .

5. All applicable water quality standards set under Section 1102.F, Subpart H (Sections 2100 through 2805) and Section 3101 shall be attained at the boundaries of mixing zones.... 
Ohio (Ohio Administrative Code)

Permit application regulations:

3745-1-05 Antidegradation

(D) Exclusions and waivers.

(1) The following situations are excluded from the submittal and review requirements listed in paragraphs (B)(2)(c) to (B)(2)(g), (C)(6) and (C)(8) of this rule.

(a) Any source discharging to limited quality waters

(b) For general high quality waters, any net increase in the discharge of a regulated pollutant from an existing source, up to a total of eighty percent of the wasteload allocation to maintain water quality standards calculated using total maximum daily load procedures, if the source was issued an NPDES permit prior to 7/1/93 that contained existing effluent quality based permit limitations for that regulated pollutant.

(c) Any de minimis net increase determined using the following criteria: [different criteria for different qualities of water] ....

(4) The director may waive the requirements listed in (B)(2)(e) to (B)(2)(g), (C)(6) and (C)(8) of this rule if it is determined that:

(a) The proposed net increase in the discharge of a regulated pollutant does not result in an increase in the ambient water quality concentration of the receiving water after mixing as projected to occur under the total maximum daily load procedures;

(b) Any proposed net increase in the discharge of ... toxic substances complies with all applicable water quality standards and will not threaten environmentally sensitive areas such as downstream lakes, reservoirs, .... and

(c)The requirements of paragraph (B)(2)(d) have been met and the director determines that none of the [more environmentally protective alternatives] for the design and operation of the activity are technically feasible and economically justifiable.

Mixing zone regulations:

3745-1-06 Mixing Zones

(A) Non-thermal

(3) When establishing a mixing zone, the director shall require that the concentration of pollutants in the zone beyond the area of initial mixing not exceed at any time the final acute value or the forty-eight- to ninety-six-hour median tolerance limit (TLM) or LC50 for any representative aquatic species. Only data for life stages that have the potential to inhabit the mixing zone in the absence of toxicity will be considered. Toxicity data are determined from applicable scientific literature or as determined by static bioassays for persistent toxicants and dynamic bioassays for nonpersistent toxicants in accordance with the methods described in "Standard Methods for the Examination of Water and Wastewater," or "Manual of Ohio EPA Surveillance Methods and Quality 
Assurance Practices," as cited in paragraph (B) of rule 3745-1-03.

(4) For lakes and reservoirs (except Lake Erie) defined as state resource waters by rule 37451-05, no mixing zone shall be permitted.

Antidegradation regulations:

\section{5-1-05 Antidegradation}

(B) Applicability; responsibilities of the applicant. Except as provided in paragraph (D), projects or activities covered under paragraph (B)(1) shall be subject to an antidegradation review described in paragraph (C).

(1)(a) For existing sources, any NPDES permit that would result in a net increase in the discharge of any regulated pollutant as determined by the following criteria:

(I) Net increase of the average thirty-day mass limit specified in the NPDES permit;

(ii) If no average mass limit is specified, then a net increase above the product of:

(a) The average concentration limit specified in the NPDES permit, if an average concentration limit is specified, and

(b) The permitted discharge flow or the flow used in the wasteload allocation;

(iii) If neither an average mass limit nor an average concentration limit are specified, then a net increase above the product of:

(a) An average concentration value derived from the maximum concentration limit specified in the NPDES permit, if one is specified, using derivation methods established in the total maximum daily load procedures, and

(b) The permitted discharge flow or the flow used in the wasteload allocation;

(iv) If the NPDES permit specifies no limit for the pollutant, then the imposition of any effluent limit if the pollutant is present, or present in greater amounts, because of any of the following conditions:

(a) A physical change in, or change in the operation of, a publicly owned treatment works; or

(b) The addition of a significant industrial user, as defined in rule 3745-3-01 of the Administrative Code; or

(c) A physical change in, or change in the operation of, industrial processes and/or wastewater treatment at a significant industrial user; or

(d) A physical change in, or change in the operation of, industrial processes and/or wastewater treatment at a permitted facility other than a publicly owned treatment works. 
Oklahoma (Oklahoma Administrative Code)

Biocide-specific regulations:

785:46-3-1. Applicability and scope.

(d) Toxicity from halogens (e.g., chlorine, bromine and bromo-chloro compounds) will be controlled by dehalogenation rather than WET testing. However, use of dehalogenation shall not exempt an effluent from WET testing requirements ...

The state water quality standards for TRC or TRO is no measurable quantity, which is determined to be $<0.1 \mathrm{mg} / \mathrm{l}$. It is also dependent upon the volume of discharge in proportion to the receiving stream.

Water quality standards regulations (general):

785:45-5-12. Fish and wildlife propagation.

(E) Criteria used in protection of fish and wildlife propagation. The narrative and numerical criteria shall include:

(6) Toxic substances (for protection of fish and wildlife).

(d) For toxicants not specified in the table following (G) of this paragraph, concentrations of toxic substances with bio-concentration factors of 5 or less shall not exceed 0.1 of published LC50 value(s) for sensitive representative species using standard testing methods, giving consideration to site specific water quality characteristics.

785:45-5-25 Implementation Policies for the Antidegradation Policy Statement.

(a) (1) The limitations contained in 785:45-5-25(c)(1) for additional protection of Outstanding Resource Waters (ORW) shall apply to all discharges from point sources except such limitations do not apply to discharges of stormwater from temporary construction activities....

(c) The following limitations for additional protection apply to various waters of the state:

(1) $O R W$

(B) The following waterbodies are prohibited from having any new point source discharge(s) of any pollutant or increased load of any pollutant from existing point source discharge(s):

(I) Water bodies designated "ORW" and/or "Scenic River" in Appendix A of this Chapter;

(ii) Waterbodies located within the watersheds of waterbodies designated "Scenic River" in Appendix A; and

(iii) Waterbodies located within the boundaries of Appendix B areas which 
are specifically designated "ORW" in Appendix A.

(3) High Quality Waters (HQW). [No new discharges of any pollutant or increased load or concentration of specified pollutants from existing point source discharge(s) are allowed unless approved by the Board upon demonstration that such discharges will maintain or improve the level of water quality necessary to support recreation and propagation of fishes, shellfishes, and wildlife of the direct receiving water and downstream water bodies designated HQW. No discharge of any pollutant to a HQW may lower existing water quality.]

(4) Sensitive Public and Private Water Supplies (SWS). [No new discharges of any pollutant or increased load or concentration of specified pollutants from existing point source discharge(s) are allowed, unless approved by the Board upon demonstration that such discharges will not lower water quality of either the direct receiving water or downstream water bodies designated SWS.]

Methods to determine water quality-based effluent limitations (regulations):

785:46-3-1 Applicability and scope.

(b) If effluent toxicity is not persistent, increased toxicity testing to determine the source of toxicity is required.

(c) If it is determined that toxicity is related to a particular chemical constituent, a numerical permit limit may be imposed for that toxicant.

Permit application regulations:

\section{2:605-7-3. Reporting change in discharge or treatment}

(c) Any anticipated facility expansions, production increases, or process modifications which will result in new or different pollutants or increased discharge (concentration, loading or volume) of pollutants, disposal of sludge or other waste disposal or treatment practices, must be reported by submission of a new application to the Department prior to such changes. If such changes will not violate the effluent limitations or other terms specified in a permit or authorization issued by the department, they shall be reported by giving prior written notice to the Department.

(d) Upon receipt of such application or notice, or on its own initiative, the Department may modify the permit or authorization to specify and limit any pollutant(s) not previously limited, deny the application, or take other appropriate actions ...

Mixing zone regulations: 
785:45-5-26. Mixing zones and zones of passage

(a) (2) Acute toxicity within the mixing zone is prohibited.

(3) Mixing zones in lakes shall be designated on a case-by-case basis.

(4) The water quality in a portion of the mixing zone may be unsuitable for certain beneficial uses. 
Pennsylvania (Pennsylvania Code)

Biocide-specific regulations:

Chapter 93. Water Quality Standards

93.5(f)(1)-(2) (Total Residual Chlorine criteria):

Facilities must meet the more stringent of either an effluent limitation representing BAT for discharge of TRC, or a water-quality based effluent limitation developed in accordance with section 93.5 (a) or (b) [re: design conditions], as applicable, which attains the water quality criteria for TRC specified in section 93.7(c), Table 3.

Facilities utilizing chlorine, which discharge to Exceptional Value Waters, as defined in section 93.3 (relating to protected water uses), or High Quality Waters, as defined in section 93.3, where necessary economic or social justification of significant public value and other factors have not been demonstrated under section 95.1(b) (relating to general requirements), shall dechlorinate their effluents prior to discharge into the waters.

Water quality standards regulations (general):

\section{Chapter 16. Water Quality Toxics Management Strategy--Statement of Policy} 16.22(2)-(3) (Criteria Development):

For those toxics for which EPA has not developed criteria due to an inadequate database to fit the National guidelines, the state must develop aquatic life criteria using best scientific information available. For those toxics for which there are insufficient data to fit the EPA National Guidelines or state guidelines, the state will impose criteria to protect statewide uses [in section 93.4], monitor-only requirements or technology-based limits until sufficient data become available to develop in-stream criteria for aquatic life protection. 
Texas (Texas Administrative Code)

\section{Biocide-specific regulations:}

[The permittee generally would provide to the state written notification of their wish to discharge a particular biocide, and would submit a material safety data sheet (MSDS). The state would review the information and determine if any additional information were necessary].

Water quality standards regulations (general):

Chapter 307, Section 307.6 - Toxic Materials.

(c) Specific numerical aquatic life criteria.

(7) For toxic materials for which specific numerical criteria are not listed, the appropriate criteria for aquatic life protection may be derived in accordance with current EPA guidelines .... When insufficient data are available to use EPA guidelines, the following provisions shall be applied in accordance with this section and 307.8 of this title.

(A) acute criteria will be calculated as 0.3 of the LC50 of the most sensitive aquatic organism; LC50 x (0.3) = acute criteria;

(B) concentrations of non-persistent toxic materials shall not exceed concentrations which are chronically toxic (as determined from appropriate chronic toxicity data or calculated as 0.1 of acute LC50 values) to the most sensitive aquatic organisms; LC50 x (0.1) = chronic criteria;

(Gc) concentrations of persistent toxic materials that do not bioaccumulate shall not exceed concentrations which are chronically toxic (as determined from appropriate chronic toxicity data or calculated as 0.05 of LC50 values) to the most sensitive aquatic organisms; and

(D) concentrations of toxic materials that bioaccumulate shall not exceed concentrations that are chronically toxic (as determined from appropriate chronic toxicity data or calculated as 0.01 of LC50 values) to the most sensitive aquatic organisms.

(8) For toxic substances where the relationship of toxicity is defined as a function of $\mathrm{pH}$ or hardness, numerical criteria are presented as an equation based on this relationship. . . 
Whole effluent toxicity testing regulations:

Chapter 307. Surface Water Quality Standards

307.6 Toxic Materials.

(c) Specific numerical aquatic life criteria.

(4) Ammonia and chlorine toxicity will be addressed by total toxicity biomonitoring requirements in subsection (e) of this section.

[Typically, the state requires biomonitoring as a testing mechanism for determining whether a particular biocide may be discharged under a permit. They do not typically use the MSDS and LC50 value and work backward to derive a standard.]

(e) Total toxicity.

(1) Total (whole effluent) toxicity of permitted discharges, as determined from biomonitoring of effluent samples at appropriate dilutions, will be sufficiently controlled as to preclude acute total toxicity in all water in the state with the exception of small zones of initial dilution at discharge points (ZIDs). Acute total toxicity levels may be exceeded in a ZID, but there shall be no lethality to aquatic organisms which move through a ZID, and the sizes of ZIDs are limited in accordance with 307.8 of this title (relating to application of standards). Chronic total toxicity, as determined from biomonitoring of effluent samples, will be precluded in all water in the state with existing or designated aquatic life uses except in mixing zones and at flows less than critical low-flows, in accordance with 307.8 of this title.

(2) General provisions for controlling total toxicity.

(A) Dischargers whose effluent has a significant potential for exerting toxicity in receiving waters will be required to conduct whole effluent toxicity biomonitoring at appropriate dilutions.

Mixing zone regulations:

Chapter 307, section 307.8 - Application of Standards

(b) Mixing zones. A reasonable mixing zone will be allowed at the discharge point of permitted discharges into surface water in the state, in accordance with the following provisions.

(1) The following portions of the standards do not apply within mixing zones:

(B) numerical chronic aquatic life criteria for toxic materials as established in 307.6 of this title (relating to toxic materials);

(C) total chronic toxicity restrictions as established in 307.6;

(H) specific human health criteria for concentrations in water to prevent contamination of drinking water, fish and shellfish so as to ensure safety for human consumption, as established in 307.6. 
(2) Numerical acute aquatic life criteria for toxic materials and preclusion of total acute toxicity as established in 307.6 are applicable in mixing zones. Acute criteria and acute total toxicity levels may be exceeded in small zones of initial dilution (ZIDs) at discharge points, but there shall be no lethality to aquatic organisms which move through a ZID. ZIDs shall not exceed the following sizes: ....

(3) Provisions of the general criteria in 307.4 of this title remain in effect in mixing zones unless specifically exempted in this section

(4) Water quality standards do not apply to treated effluents at the immediate point of discharge-prior to any contact with either ambient waters or a dry streambed. However, effluent total toxicity requirements may be specified to preclude acute lethality near discharge points, or to preclude acute and chronic instream toxicity. 
Washington (Washington Administrative Code)

Biocide-specific regulations:

Chapter 173-201A WAC: Water Quality Standards for Surface Waters of the State of Washington

173-201A-040 Toxic substances.

(3) The following criteria shall be applied to all surface waters of the state of Washington for the protection of aquatic life. ... Values are $\mathrm{mg} / \mathrm{L}$....

Chlorine (Total Residual): Freshwater, Acute - 19.0; Chronic - 11.0. Marine water, Acute 13.0; Chronic - 7.5.

Water quality standards regulations (general):

Chapter 173-201A WAC: Water Quality Standards for Surface Waters of the State of Washington

173-201A-040 Toxic substances.

(1) Toxic substances shall not be introduced above natural background levels in waters of the state which have the potential either singularly or cumulatively to adversely affect characteristic water uses, cause acute or chronic toxicity to the most sensitive biota dependent upon those waters, or adversely affect public health, as determined by the department.

(2) The department shall employ or require chemical testing, acute and chronic toxicity testing, and biological assessments, as appropriate, to evaluate compliance with subsection (1) of this section and to ensure that aquatic communities and the existing and characteristic beneficial uses of waters are being fully protected.

(5) Concentrations of toxic, and other substances with toxic propensities not listed in subsection (1) of this section shall be determined in consideration of EPA Quality Criteria for Water, 1986, and as revised, and other relevant information as appropriate.

Mixing zone regulations:

WAC 173-201A-100 Mixing zones.

(2) A discharger shall be required to fully apply all known, available, and reasonable methods of prevention, control, and treatment prior to being authorized a mixing zone.

(4) No mixing zone shall be granted unless the supporting information clearly indicates the mixing zone would not have a reasonable potential to cause a loss of sensitive or important habitat, substantially interfere with the existing or characteristic uses of the water body, result in damage to the ecosystem, or adversely affect public health as determined by the department. 
(5) Water quality criteria shall not be violated outside of the boundary of a mixing zone as a result of the discharge for which the mixing zone was authorized.

(7) The maximum size of a mixing zone shall comply with the following:

(d) In lakes, and in reservoirs having a mean detention time greater than fifteen days, mixing zones shall not be allowed unless it can be demonstrated to the satisfaction of the department that:

(I) Other siting, technological, and managerial options that would avoid the need for a lake mixing zone are not reasonable achievable;

(ii) Overriding considerations of the public interest will be served; and

(iii) All technological and managerial methods available for pollution reduction and removal that are economically achievable would be implemented prior to discharge. Such methods may include, but not be limited to, advanced waste treatment techniques.

(8) Acute criteria are based on numeric criteria and toxicity tests approved by the department, ... and shall be met as near to the point of discharge as practicably attainable. Compliance shall be determined by monitoring data or calibrated models approved by the department utilizing representative dilution ratios. A zone where acute criteria may be exceeded is allowed only if it can be demonstrated to the department's satisfaction the concentration of, and duration and frequency of exposure to the discharge, will not create a barrier to the migration or translocation of indigenous organisms to a degree that has the potential to cause damage to the ecosystem. A zone of acute criteria exceedance shall singularly or in combination with other such zones comply with the following maximum size requirements: . . . 
West Virginia (West Virginia Code of State Regulations)

Biocide-specific regulations:

Appendix E [contains water quality standards for acute and chronic toxic substances, for different substances, for aquatic life and human health for different classes of waters] ...

8.31 Total Residual Chlorine (ug/l - measured by amperometric or equivalent method) Not to exceed: for aquatic life, B1: 19; for B4: 11. For human health, C3: 10; for A4: 10

8.31.1 No chlorinated discharge allowed: applicable to Aquatic Life--B2.

Water quality-based effluent limitations regulations:

\section{6-1-9. Establishment of Safe Concentration Values}

When a specific water quality standard has not been established by these rules and there is a discharge or proposed discharge into waters of the State, the use of which has been designated a Category B1, B2, B3 or B4, such discharge may be regulated by the chief where necessary to protect State water through establishment of a safe concentration value as follows: ...

Methods to determine water quality based effluent limitations regulations:

\section{6-1-9. Establishment of Safe Concentration Values}

9.2. In those cases where it has been determined that there is insufficient available data to establish a safe concentration value for a pollutant, the safe concentration value shall be determined by applying the appropriate application factor as set forth below to the 96-hour LC 50 value. Except where the chief determines, based upon substantial available scientific data that an alternate application factor exists for a pollutant, the following appropriate application factors shall be used in the determination of safe concentration values:

a. Concentrations of pollutants or combinations of pollutants that are not persistent and not cumulative shall not exceed 0.10 of the 96-hour LC 50

b. Concentrations of pollutants or combinations of pollutants that are persistent or cumulative shall not exceed 0.01 of the 96-hour LC 50.

Mixing zone regulations:

46-1-5. Mixing Zones.

5.2 The following guidelines and conditions are applicable to all mixing zones:

b. Concentrations of pollutants which exceed the acute criteria for protection of aquatic life set forth in Appendix E shall not exist at any point within an assigned mixing zone or in the discharge itself unless a zone of initial dilution is assigned .... Concentrations of pollutants shall 
not exceed the acute criteria at the edge of the assigned zone of initial dilution. Chronic criteria for the protection of aquatic life may be exceeded within the mixing zone but shall be met at the edge of the assigned mixing zone.

c. Concentrations of pollutants which exceed the criteria for the protection of human health set forth in Appendix E shall not be allowed at any point unless a mixing zone has been assigned.... Mixing zones .... shall be developed using reasonable assumptions about exposure pathways.... No mixing zones for human health criteria shall be established on a stream which has a seven (7) day, ten (10) year return frequency of 5 cubic feet per second or less. 
Wisconsin (Wisconsin Administrative Code)

Biocide-specific regulations:

NR 105.06 Chronic Toxicity Criteria for Fish and Aquatic Life

[contains requirements for minimum database for chronic criterion development; for calculation of chronic concentration; for chronic toxicity criteria for substances with toxicity unrelated to water quality parameters; and for chronic toxicity criteria for substances with toxicity related to water quality parameters; for acute-chronic ratios]

Table 1 Acute Toxicity Criteria for Substances With Toxicity Unrelated to Water Quality: (in ug/l). .

Chlorine (Total residual): 18.4

Table 5 Chronic Toxicity Criteria Using Acute-Chronic Ratios for Substances With Toxicity Unrelated to Water Quality (in $\mathrm{mg} / \mathrm{l}$ )...

Chlorine (Total residual): 7.06

Cooling water-specific regulations:

NR 106.10 Exclusions.

(1) Noncontact Cooling Water. Except as provided in subsection (2), the department may not impose water quality based effluent limitations for toxic and organoleptic substances for discharges of ... non-contact cooling waters which do not contain additives or combined discharges consisting solely of uncontaminated stormwater runoff and noncontact cooling water without additives. Only the additives to noncontact cooling waters shall be examined under this chapter for the establishment of water quality based effluent limitations. For purposes of this exclusion, the term "additives" are those compounds intentionally introduced by the discharger, but do not include the addition of compounds at a rate and quantity necessary to provide a safe drinking water supply, or the addition of substances in similar type and amount to those substances typically added to public drinking water supply. The following may be used to establish water quality based effluent limitations for noncontact cooling waters:

(a) If at least one 48-hour LC50 or EC50 value is available for daphnia magna and at least one 96-hour LC50 or EC50 value is available for either fathead minnow, rainbow trout, or bluegill, the geometric mean LC50 or EC50 for each of these species shall be divided by 5 if rainbow trout are represented in the data base or divided by 10 if rainbow trout are not represented in the data base. The limitation for purposes of this section shall be equal to the lowest resultant value. A limitation

can be calculated for an additive only if both LC50 and EC50 data for daphnia magna and at least 
one of the fish species listed above are available.

(b) Effluent limitations based on chronic toxicity to aquatic life shall be established using the procedures described in this paragraph for additives whenever chronic toxicity criteria are not available from NR 105.06. The calculation of limitations shall be in accordance with the requirements of NR 106.06(3)(b). In this calculation, the water quality criterion concentration shall be equal to the final acute value for that additive as provided in NR 105.05, or the effluent limitation as determined in paragraph (a), divided by the geometric mean of all the vertebrate and invertebrate species mean acute-chronic ratios determined in accordance with NR 105.06(5) for that additive. A water quality criterion concentration may be calculated for an additive only if a final acute value, as provided in NR 105.05 or an effluent limitation as determined in paragraph (a), and an acute-chronic ratio for a vertebrate species and an acute-chronic ratio for an invertebrate species are available.

Water quality-based effluent limitations regulations:

Chapter NR 106 Procedures for Calculating Water Quality Based Effluent Limitations for Toxic and Organoleptic Substances Discharged to Surface Waters

106.05 Determination of the necessity for water quality based effluent limitations for toxic and organoleptic substances.

(2) The department shall consider in-stream biosurvey data and data from ambient toxicity analyses whenever such data are available.

(3) If representative discharge data are available for a toxic or organoleptic substance being discharged from a point source, limitations shall be established in accordance with any one of the following conditions:

(a) The discharge concentration of the substance for any day exceeds the limit of detection and exceeds the limitations based on acute toxicity for the substance as determined in NR 106.06(2) where appropriate.

(b) The arithmetic average discharge concentration of the substance for any 4 consecutive days calculated as described in subsection (7) exceeds the limit of detection and exceeds any limitations based on either the chronic toxicity criterion or final chronic value for the substance as determined in NR 106.06(3).

(c) The arithmetic average discharge concentration of the substance for any 30 consecutive days calculated as described in subsection (7) exceeds the limit of detection and exceeds any limitation based on the wild and domestic animal, human threshold, human cancer, or taste and odor criteria for the substance as determined in NR 106.06(3).

(8) If representative discharge data are not available for a substance, water quality based effluent limitations may be established if, in the judgment of the department, water quality standards will be exceeded if the discharge from the point source is not limited.

Chapter NR 104 Uses and Designated Standards 
NR 104.02 Surface water classifications and effluent limitations.

(4) Other Classifications and Effluent Criteria.

(a) ... Under all hydrologic categories, the department reserves the right to require other effluent limitations, including allocation of wasteloads for organic material, toxicants and chlorine residuals if it is determined that the specified surface water is important to the overall environmental integrity of the area....

(b) Surface waters classified for fish and aquatic life.

1. Streams. Where flowing streams or rivers are specified to achieve fish and aquatic life criteria, wasteload allocation for organic material, toxicants and chlorine residuals shall determine effluent criteria necessary to achieve that standard.

\section{Chapter NR 207 Water Quality Antidegradation}

NR 207.03 Antidegradation evaluation procedure.

(1) Outstanding resource waters. If the department determines that a permit application proposes a new or increased discharge to outstanding resource waters, effluent limitations for substances in the new or increased portion of the discharge will be set equal to the background levels of these substances, upstream of, or adjacent to, the discharge site unless it is determined that for tributaries to Great Lakes waters, such limitations would result in significant lowering of water quality under NR 207.05(4)(b). Effluent limitations for those substances shall be determined in accordance with NR 207.04.

NR 207.04 Fish and aquatic life waters.

(2) Departmental determinations.

(a) If the department determines that the existing wastewater treatment facilities have treatment capability to treat any proposed new or increased discharge and maintain treatment levels sufficient to meet existing effluent limitations as documented under subsection (1)(a), effluent limitations will remain unchanged.

(b) If the department determines that the existing treatment facilities do not have treatment capability to treat any proposed new or increased discharge and maintain treatment levels sufficient to meet existing effluent limitations, effluent limitations will be developed using the following procedures: ...

(c) The department shall use the following procedures to determine water quality based effluent limitations or effluent limitations determined pursuant to NR 200-297 as appropriate, for each substance in the proposed new or increased discharge for which the existing levels upstream of, or adjacent to, the discharge site are of better quality than applicable water quality criteria in NR 102, 103 or $105:$...

(d) The department shall determine water quality based effluent limitations using the water quality criteria in NR 102, 103, 104 or 105 for substances in the proposed new or increased discharge whose levels in the receiving water are of lesser quality than the water quality criteria for 
the receiving water upstream of, or adjacent to, the discharge site.

(e) In addition to the provisions of paragraphs (a) to (c), if the department determines that a proposed new or increased discharge will result in lowering of water quality in downstream outstanding resource waters or a proposed new discharge would result in lowering of water quality in exceptional resource waters, other than for the reasons specified in NR 207.03(2)(a), water quality based effluent limitations for substances in the new or increased portion of the discharge will be set to prevent the lowering of water quality in the downstream outstanding or exceptional resource water. Whenever NR 207.03(2)(a) applies, effluent limitations shall be established using the procedures in this section.

Methods to determine water quality-based effluent limitations:

NR 106.06 Calculation of water quality based effluent limitations for toxic and organoleptic substances.

(2) Limitations based on acute toxicity.

(a) The department shall establish water quality based effluent limitations to ensure that substances are not present in amounts which are acutely harmful to animals, plants, or aquatic life in all surface waters including those portions of the mixing zone normally habitable by aquatic live and effluent channel as required by section NR 102.4(1).

(c) Water quality based effluent limitations may exceed the final acute value as determined in section NR 105.05 within a zone of initial dilution provided that the acute toxicity criteria as determined in NR 105.05 are met within a short distance from the point of discharge. A zone of initial dilution shall only be provided if the discharger demonstrates to the department that mixing of the effluent with the receiving water in the zone of initial dilution is rapid and all the following conditions are met: ....

(3) Limitations based on chronic toxicity or long-term impacts.

(a) Water quality criteria. The department shall calculate water quality based effluent limitations to ensure that the chronic toxicity criteria, the wild and domestic animal criteria, the taste and odor criteria, the human threshold criteria, and human cancer criteria appropriate for the receiving water as specified in chapters NR 102 to 105 will be met after dilution with an appropriate allowable quantity of receiving water flow as specified in this subsection, subsections (4) to (8) and NR 106.11.

(7) Environmental fate. The limitations calculated pursuant to this section may be modified to account for degradation of the substance based on information available to the department provided that: ...

Whole effluent toxicity testing regulations:

NR 106.08 Determination of the necessity of whole effluent toxicity testing requirements and 
limitations.

(1) ... When considering the necessity of whole effluent toxicity testing requirements and limitations, the department shall consider in-stream biosurvey data and data from ambient toxicity analyses, whenever such data are available.

(2) If representative discharge data are available for an effluent being discharged from a point source, whole effluent toxicity testing requirements are necessary when:

(a) Existing aquatic life toxicity test data generated according to standard test protocols indicate a potential for an effluent from a point source discharge to adversely impact the receiving water aquatic life community.

(b) A water quality based effluent limitation for a toxic substance is determined necessary in NR 106.05.

(3) If no representative discharge data are available for an effluent being discharged from a point source, whole effluent toxicity testing requirements are necessary if, in the judgment of the department, water quality standards may be exceeded. In such cases, the following factors may be considered: ... .

(4) Regardless of the results of the analysis conducted under this section, the department may, whenever determined necessary, require whole effluent toxicity testing for a point source discharge. $\cdots$

(5) Whole effluent toxicity limitations are necessary when representative whole effluent toxicity data indicated toxicity to aquatic life as determined in NR 106.09.

Permit application regulations:

NR 207.05 Determining significant lowering of water quality.

(2) Application Information. Persons proposing a new or increased discharge shall use the following procedure to demonstrate to the department whether the discharge will result in a significant lowering of water quality:

(c) Calculate expected levels in the receiving water of the indicator parameters as a result of the proposed new or increased discharge. In calculating the expected levels in the receiving water, the following shall be used:

1. Applicable design low flow rates or dilution ratios for the receiving water in NR 102 or 106 or specified by the department if none of those rates or ratios apply.

2. The daily average discharge loading rates for the new or increased portion of a municipal discharge or the yearly average discharge loading rates for the new or increased portion of an industrial discharge.

(d) Compare the expected levels in the receiving water of each indicator parameter as 
calculated in paragraph (c) to:

1. The assimilative capacity multiplied by one-third for all indicator parameters except dissolved oxygen; or

2. The sum of the existing level multiplied by two-thirds and the water quality criterion multiplied by one-third for dissolved oxygen.

(3) Procedure Waiver. Persons proposing a new or increased discharge may choose to waive the procedure in subsection (2), and proceed directly to the economic and social development test in NR 207.04(1)(c).

(4) The department shall determine that a proposed new or increased discharge will result in a significant lowering of water quality if either:

(a) The proposed new or increased discharge, ... . taking into account any changes in assimilative capacity over time that have been demonstrated under subsection (2)(b), results in an expected level of an indicator parameter in the receiving water of either of the following:

1. Greater than one-third multiplied by the assimilative capacity for any indicator parameter other than dissolved oxygen; or

2. Greater than the sum of the existing level multiplied by two-thirds and the water quality criterion multiplied by one-third for dissolved oxygen.

(b) For a discharge to Great Lakes waters or their tributaries, the mass loading to the receiving water of any substance in the proposed new or increased discharge having a bioaccumulation factor greater than 250 would be increased.

Mixing zone regulations:

Chapter NR 102 Water Quality Standards for Wisconsin Surface Waters

NR 102.05 Application of standards.

(3) Mixing zones.

(D) Final acute values specified in or developed pursuant to NR 105.05 for the fish and aquatic life subcategory, for which the receiving water is classified, not being exceeded at any point in the mixing zone. 
Wyoming (Wyoming Department of Environmental Quality Rules and Regulations)

Water quality standards regulations (general):

Chapter 1. Quality Standards for Wyoming Surface Waters

Section 21. Protection of Aquatic Life.

(b) Specific numeric standards for a number of toxicants are listed in the aquatic life "acute value" and "chronic value" columns in Appendix B. These standards apply to all class 1,2, and 3 waters. For these pollutants, the chronic value (four day average concentration) and the acute value (one hour average concentration) shall not be exceeded more than once every three years.

(c) Others - For those pollutants not listed in Appendix B or C, maximum allowable concentrations shall be determined through the bioassay procedures outlined in the references in Appendix E.

Appendix B -- Water Quality Criteria

Non-Priority Pollutants

Chlorine (total recoverable): Aquatic Life Acute Value - 19 ug/l; Aquatic Life Chronic Value - 11 ug/l; Human Health Value - [none identified]

Water quality-based effluent limitations regulations:

Chapter 1. Quality Standards for Wyoming Surface Waters

Section 7. Class 1 Waters.

(a) No new point sources, other than dams, may discharge, and no existing point sources, other than dams, may increase their quantity of pollution discharge, to any water designated as Class 1.

(b) The department shall impose whatever controls are necessary on point source discharges to tributaries of Class 1 waters. Such discharges shall not degrade the quality of any Class 1 water below its existing quality.

Mixing zone regulations: 
Chapter 1. Quality Standards for Wyoming Surface Waters

Section 9. Mixing Zones

Except for Sections 14-17 and 28 of these regulations, compliance with water quality standards shall be determined after allowing a reasonable time for mixing. Except for the zone of initial dilution, which is the initial $10 \%$ of the mixing zone, the mixing zone shall not contain pollutant concentrations that exceed the acute aquatic life values (see Appendix B). In addition, there shall be a zone of passage around a mixing zone which shall not contain pollutant concentrations that exceed the chronic aquatic life values (see Appendix B). 